\title{
Gazete Haberlerini Konu Alan Yüksek Lisans Tezlerine Dair Bibliyometrik Bir Analiz ${ }^{1}$
}

\section{A Bibliometric Analysis of the Master's Theses Dealing with Newspaper News}

\author{
Arş. Gör. Mehmet Pelivan ${ }^{2}$
}

Başvuru Tarihi: 06.03.2019

Kabul Tarihi: 26.12.2019

\section{Öz}

Bilginin geçmişi ve geleceği ile ilgili iki temel yaklaşımdan ilki, bilginin birikimli bir şekilde ilerlediği ve yapılacak çalışmaların geçmişteki bilgiden yararlanarak gelişme sağlayacağı fikrine dayanmakta ve günümüzde güçlü bir şekilde kabul görmektedir. İkinci olarak ise varolan bilginin yıkılarak yenilerinin inşa edileceği, gelişmelerin sağlanacağı kabulüdür ve birinci yaklaşımın tam karşısına konumlanmaktadır. Özellikle bazı kuramsal yaklaşımların, varolan bilgiyi tamamen ortadan kaldırarak kurulduğu hatırlandığında bu bakış açısının da önemli bir kapsayıcıllğı olduğu kabul edilmelidir. Bilgiyle ilgili her iki yaklaşımda da bir alanı, konuyu ya da literatürü ele alan çalışmaların bütünlüklü bir değerlendirilmesi kaçınılmazdır. Kısacası bir kuramsal anlayışı yıkmak ya da doğrulamak için ilgili literatüre kapsamlı bir şekilde hâkim olmak ve literatürü tartışmak ihtiyacı her zaman vardır.

Bu çalışmada da Türkiye'de gazete haberlerini konu alan ve dolayl ya da doğrudan ideoloji tartışması yapan yüksek lisans tezlerinin, değerlendirme için gerekli literatürü oluşturduğu varsayımından hareketle söz konusu çalışmaların yıl ve üniversite bağlamında dă̆glımlarını ve değişimlerini ortaya koymak amaçlanmıştır. Bu amaç doğrultusunda üniversite ve yıl başlıkları altında çalışmaların, anabilim dallarına, konularına, kuramsal yaklaşımlarına, yöntemlerine, hipotezlerine ve inceledikleri gazetelerin kapsamına göre nasıl dağılım ve değişim gösterdiği sorularına cevap aranmıştır. Sorulara cevap bulmak için bibliyometrik çözümleme yöntemi kullanılmış, nicel olarak toplanan veriler, tablolar şeklinde sunulmuş ve incelenmiştir.

Anahtar Kelimeler: İletişim Araştırmaları, İdeoloji, Yüksek Lisans Tezleri, Gazete Haberleri, Bibliyometrik Yöntem

\section{Abstract}

The first of the two basic approaches to knowledge and the future of knowledge are based on the idea that knowledge progresses cumulatively and that the studies to be done, should progress by making use of knowledge in the past. This understanding is widely and strongly accepted today. The second one is the acceptance of the existing knowledge to be destroyed and the new ones to be constructed and to be

\footnotetext{
${ }^{1}$ Bu makale Ankara Üniversitesi Sosyal Bilimler Enstitüsü Gazetecilik Anabilim Dalı’nda tamamlamış olduğum “Türkiye'de Gazete Haberlerini Konu Alan Yüksek Lisans Tezleri: Yöntem Sorunsalı, Eğilimler ve İdeoloji Kavramlaştırmaları” başlıklı yüksek lisans tezimin bir bölümünün tekrar düzenlenmiş halidir. Ayrıca makalede yer alan verilerin küçük bir kısmı "İdeoloji Çözümlemesi Yapan Yüksek Lisans Tezlerine Dair Bibliyometrik Bir Analiz” başlığıyla Eskişehir'de düzenlenen 16th International Symposium “Communication in the Millennium”da bildiri olarak sunulmuştur.

${ }^{2}$ Ankara Üniversitesi İletişim Fakültesi, plvnmhmt@gmail.com, ORCID: 0000-0002-3745-0780
} 
developed and is situated directly opposite the first approach. It should be accepted that this perspective is also an important comprehensiveness, especially when some of the theoretical approaches are remembered to be established by completely removing the existing knowledge. In both approaches to information, it is inevitable to have a holistic assessment of studies that deal with a field, subject, or literature. In short, there is always a need to thoroughly master the relevant literature and discuss the literature in order to break down or confirm a theoretical understanding.

In this study, I acted on the assumption that the master theses which deals with the newspaper news and examines ideology direct and indirect in Turkey have created the necessary literature for the assessment. My aim of this study is to reveal the distribution and changes of these studies in the context of year and university. I analyzed these theses under the headings of university and period according to how the theses were distributed the following information: departments, prominent topics, theoretical approaches, methods, hypotheses, and the scope of newspapers they investigated. I used the bibliometric method in the study and gathered data as quantitative. I have presented and analyzed these data in tables.

Keywords: Communication Researches, İdeology, Master Theses, Newspaper News, Bibliometric Method

\section{Giriş}

Günümüzde bilginin ilerlemesi ya da birikmesi konusunda iki yaklaşım dikkat çekicidir. Bunların ilkinde 'bilginin birikimli biçimde ilerlediği' şeklinde kabul görmüş güçlü bir eğilim söz konusudur. $\mathrm{Bu}$ varsayımından hareketle bir alan ya da konu üzerinde çalışmaların belli bir mesafe kat etmesi sonucunda ortaya çıkan araştırmaların değerlendirilmesi, gelecekte yapılacak çalışmalar açısından hayati bir önem taşımaktadır. Araştırmacıların ilgilendiği konu hakkında literatüre hâkim olması, eğilimleri tespit etmesi önemlidir. Eğilimlerin tespitinin yanında çalışmaların sorunlu noktalarının görülmesi de yapılacak araştırmaların nitelikli olması için kaçınılmazdır.

İkinci olarak ise bilginin birikimli şekilde ilerlediği anlayışını reddeden bakış açısına değinmek gerekir. Thomas Kuhn, bilimsel gelişmenin birikim ile sağlandığını kabul etmez. Yeni bir keşif ya da icat ile yıkılan kuramsal yaklaşımın, birikim teorisini temelden sarstığına dikkat çeker. Newton fiziğinin yıkılarak yerine Einstein fiziğinin kurulmasını da bu duruma örnek olarak gösterir (Kuhn, 2017, s. 72-78).

Bilginin birikimli bir şekilde ilerlediği varsayımından hareket ettiğimizde var olan çalışmaları değerlendirici bir araştırmanın yapılması ihtiyacı kaçınılmazdır. Belli bir literatürü sağladığı düşünülen alan ya da konuda yapılmış çalışmaları irdeleyecek araştırmaların yapılması o alan ya da konuya katkıda bulunacaktır. Bunun tam karşısında duran ve ilerleme için kuramsal anlayışın yıkılması gerektiğini savunan teoride de belli bir alan ya da konu üzerinde yapılmış araştırmaların yoğunluğunu, yönelimlerini ya da odaklandıkları noktaları ortaya koymaya ihtiyaç vardır. Kısacası her iki durumda da bir alan ya da konuyu ele alan çalışmaların bütünlüklü bir değerlendirmesi kaçınılmaz bir gerekliliktir.

Bilginin ilerlemesine ilişkin yukarıdaki değiniden sonra iletişim çalışmalarına bakarsak iletişim alanında yapılan araştırmaların önemli bir bölümü; medya kuruluşlarının kurumsal/örgütsel 
yapısını, üretilen medya içeriklerini ve bunların alımlanmasını ${ }^{3}$ sorunsallaştırmaktadır. Bu doğrultudaki çalışmalar arasında gazeteler en fazla çalışma konusu edilen araçlardan biri olarak karşımıza çıkar ve gazeteler üzerinden önemli ideoloji tartışmaları yürütülür. İletişim alanındaki yüksek lisans tezlerinde de bu ağırlık kendini göstermektedir. Bu durum yapılan çalışmaların da araştırma konusu edilmesini olanaklı kılmaktadır.

İdeoloji kavramı ilk defa, John Locke'dan etkilenen Fransız materyalist Destutt de Tracy tarafından 1796 yılında "düşünce bilimi” anlamında kullanılmıştır (Atılgan, 2015, s. 285; McLellan, 2009, s. 6). "İdea"nın "düşünce" ya da "fikir" anlamına geldiğini, -loji ekinin de belli bir alanda yapılan çalışmalara işaret ettiğini de hatırlarsak "ideoloji” nin "fikir alanında yapılan çalışmalar" biçiminde geniş bir anlama da sahip olduğunu söyleyebiliriz. Kavramın yaygın tanımı bu olmakla birlikte, farklı zamanlarda farklı düşünürler tarafından farklı şekillerde tanımlanması, ideoloji hakkında tartışmalı bir literatür ortaya çıkarmıştır. ${ }^{4}$ Günümüzde liberalliği, muhafazakârlı̆̆ı, İslamcılığı ya da faşizmi benimsemiş biri kendi bakış açısı dışındaki yaklaşımları ideolojik olarak nitelemektedir (Atılgan, 2015, s. 285). Marksistler arasında ise ideoloji üzerinde varılmış iyi-kötü, olumlu-olumsuz şeklinde bir uzlaşı bulunmamaktadır. "İdeoloji”ye bu şekilde farklı yaklaşımların gösterilmesi, iletişim alanında da karşılık bulmuş ve yapılan araştırmalarda ideoloji farklı pencerelerden sık sık tartışılan bir konu olmuştur. Ortaya çıkan bu çeşitlilik ideoloji kavramına yaklaşımları sorgulama ihtiyacını da beraberinde getirmektedir.

$\mathrm{Bu}$ çalışmada da Türkiye'de gazete haberlerini konu alan ve ideoloji tartışması yapan yüksek lisans tezlerinin değerlendirme için gerekli literatürü oluşturduğu varsayımından hareket edilmiştir. Nitekim Çiler Dursun, 1980-2003 yılları arasını kapsayan araştırmasında, incelediği yüksek lisans ve doktora tezlerinin yüzde 60,5'nin ideoloji, söylem ve temsile odaklandığını (2004, s. 101) ortaya koyarak bu varsayımı doğrulamaktadır. Hem üzerine araştırma yapılabilecek sayıda tezin tamamlanması hem de ideoloji kavramının tartışmalı doğası nedeniyle bu araştırmada Türkiye'de iletişim anabilim dalları altında yapılmış gazete haberlerini konu almış ve ideoloji tartışmasına dolaylı ya da doğrudan girmiş yüksek lisans tezlerinin yıllara ve üniversitelere göre dağılımına odaklanılmıştır. Bunun için yüksek lisans tezlerinin yıllara göre ve üniversitelere göre nasıl dağılıma sahip olduğu ve bu dağılımın nasıl değişim geçirdiği, tezlerin hangi anabilim dallarında yapıldığı, çalışmalarda ağırlıkla ön plana çıkan inceleme konularının ne olduğu, hangi kuramsal yaklaşımların benimsendiği, hangi yöntemlerin tercih edildiği, hipotez kurulup kurulmadığı ve tezlerde incelenen gazetelerin hangi ölçekte (ulusal, yabancı, yerel) olduğu sorularına cevap aranmıştır. Bu sorulara cevap bulmak için evrenin tamamı üzerinden veriler nicel biçimde bibliyometrik yöntem kullanılarak toplanmış, tablolaştırılmış ve analiz edilmiştir.

Çalışma bağlamında Türkiye'de iletişim alanında yapılmış yüksek lisans tezlerini inceleyen araştırmaların oluşturduğu literatüre bakarsak öncelikle Çiler Dursun'un "Türkiye'de Haber ve Habercilik Çalışmalarının Genel bir Değerlendirmesi: 1980-2003” başlıklı araştırmasına değinmek

\footnotetext{
${ }^{3}$ Çalışmanın evrenine dâhil edilmiş gazete haberlerini konu edinen tezlerde kurumsal yapı ve medya içeriklerine göre alımlama araştırmalarının oldukça sınırlı kaldığı görülmüştür. Ancak bu Türkiye'deki iletişim araştırmaları içerisindeki alımlama çalışmaları hakkında bir değerlendirme yapmamıza imkân tanımamaktadır. Alımlama çalışmaları hakkında bir çıkarımda bulunabilmek için iletişim araştırmaları üzerine genel bir inceleme yapma ihtiyacı vardır.

${ }^{4}$ Bkz. Eagleton, 2015; Heywood, 2014; McLellan, 2009.

${ }^{5}$ İlk olarak olumlu bir anlamda kullanılan ideoloji kelimesi Napolyon Bonaparte'nin, Moskova yenilgisi sonrası ideologları suçlamasıla olumsuz bir anlam kazanmıştır (Eagleton, 2015, s. 100).
} 
gerekir. Dursun, 2004 yılında yaptığı çalışmasında geniş bir çerçeveden haber ve habercilik pratiklerini konu alan lisansüstü tezleri, bilimsel dergilerde yayımlanmış makaleler ile kitapları ele almış ve bunları iki ana başlık altında incelemiştir. Bu başlıkların ilkinde çalışmalar yöntem ve yaklaşım bakımından sınıflandırmıştır. İkincisinde ise haber ve haberciliği konu edinen araştırmaların sorunsallarına göre dağılımlarına bakmıştır (Dursun, 2004, s. 90).

Lisansüstü tezleri araştırma konusu eden diğer bir araştırmacı da Ayşegül Çilingir'dir. Çilingir, "İletişim Alanında İçerik Analizi Yöntemï Kullanılarak Yapılan Yüksek Lisans ve Doktora Tezleri Üzerine Bir İnceleme” (2017) başlıklı makalesinin amacını, iletişim alanında yapılan tezlerde içerik analizi yönteminin kullanımına ilişkin veriler elde etmek şeklinde belirtmiştir. Çilingir, çalışmasında 1996-2015 yılları arasında tamamlanmış 64 yüksek lisans ve doktora tezini nicel yöntem kullanarak incelemiştir.

Aylin Aydoğan "Yeni İletişim Teknolojileri Tezlerinde Neo-Klasik İktisat Paradigmasının Hegomonyası" (2006) başlıklı çalışmasında hem nicel hem de nitel yöntemi kullanmıştır. Aydoğan araştırmasında, 1980'lerden sonra yeni iletişim teknolojileri üzerine yapılan yüksek lisans ve doktora tezlerini incelemiştir. Bu incelemeyi ise neo-klasik iktisat paradigmasını merkezine alarak yapmıştır. Çalışmanın nicel kısmında tezlerin türlerine (yüksek lisans ya da doktora), yıllarına, üniversitelerine ve alanlarına göre dağılımları tablolar halinde verilmiştir.

İlgili literatürde iletişim alanın kapsayıı bir şekilde tartışmayı amaç edinen çalışmalar yanında sadece halkla ilişkiler alanındaki lisansüstü tezlere değinen araştırmalarda bulunmaktadır. Bu tür çalışmalara ilk örnek Aydemir Okay ve Ayla Okay'ın “Türkiye'de Lisans ve Lisansüstü Halkla İlişkiler Eğitimi: Tezlerin Halkla İlişkiler Alanına Katkısının Kantitatif Bir Çalışması (1984-2007)” (2008) başlıklı makalesidir. Halkla ilişkiler alanında yapılmış yüksek lisans ve doktora tezlerinin içerik analiziyle değerlendirdiği bu araştırmada, çalışmalar konularına, sayılarına, diline, danışmanın durumuna, (halkla ilişkiler alanından olup olmadığı) tamamlandığı üniversiteye ve yazarların cinsiyetine göre incelenmiştir (Okay ve Okay, 2008, s. 5).

Halkla ilişkiler alanında yapılmış yüksek lisans ve doktora tezlerindeki niceliksel artışın niteliksel olarak devam edip etmediğini ortaya koymayı amaçlayan Osman Sarıer ise yüksek lisans tezinde (2014), 2003-2012 yılları arasında yapılmış lisansüstü tezleri konu edinmiştir. Sarıer, "Halkla İlişkiler Alanında Tamamlanmış Lisansüstü Tez Çalışmalarının İncelenmesi (2003-2012)” (2014) başlıklı çalışmasında, verileri geliştirdiği "tez inceleme formu" ile toplamıştır. Niceliksel başlıkta tezlerin yıllara, yapıldığı üniversitelere, yayın düzeylerine, danışman unvanlarına göre dağılımlarını ele almıştır. Nitel kısımda tezlerin konusunu, sorununu, amacını, önemini, sınırlılığını, kavramsal çerçevesini ve metodolojisini incelenmiştir (Sarıer, 2014).

$\mathrm{Bu}$ araştırmada kullanılan bibliyometrik çözümleme yöntemi, iletişim tezleri üzerine yapılan çalışmaların yalnızca birinde karşımıza çıkmaktadır. Çağrı İnceoğlu "Türkiye'de Sinemayı Konu Alan Doktora Tezleri Üzerine Bibliyometrik Bir Çözümleme” (2014) başlıklı makalesinde, Türkiye'deki sinema araştırmalarının özelliklerinin ve eğilimlerinin ortaya koymayı amaçlamıştır. İnceoğlu çalışmasında 1985-2013 yılları arasında Türkiye'de sinema konusunda tamamlanmış 199 doktora ve sanatta yeterlilik tezleri ile ilgili bilgileri bibliyometrik çözümleme kullanılarak incelemiştir. $\mathrm{Bu}$ yöntem ile tezlerin yıllara, anabilim/anasanat dallarına, yazıldıkları dillere, yöntemlerine, yaklaşımlarına, yapım türlerine (kurmaca, belgesel, canlandırma vb), temel araştırma alanlarına 
(eleştiri, tarih, kuram vb), incelediği ülke sinemalarına, anahtar kelimelerine göre dağılımları tablolar halinde ortaya konulmuştur. Son olarak bu çalışmanın incelemeyi amaç edindiği bağlamda, literatürde doktora tezlerini konu alan başka araştırmaların da olduğunu ancak kapsamları nedeniyle bu çalışmadan ayrıştıkları için burada ayrıntılandırılmadıklarını belirtmek gerekir. ${ }^{6}$ Doktora tezlerini incelmesine rağmen yukarıda sadece İnceoğlu'nun (2014) çalışmasına değinilmesinin nedeni ise iletişim araştırmalarında bibliyometrik yöntemi kullanan tek araştırma olmasıdır.

Genel olarak tezler üzerine yapılan çalışmalara baktığımızda araştırmalarda ilk olarak künye bilgileri (tamamlandığı yıl, üniversite, anabilim dalı vb.) tablolar halinde verilmiştir. Sonrasında tezlerin içeriklerine yöneltilmiş sorular (tezlerin konu dağılımları, yöntemi vb) sonucunda tablolar oluşturulmuştur. $\mathrm{Bu}$ şekilde yapılan çalışmalarda ağırlıklı olarak nicel yöntem benimsemiştir. Yukarıda bahsettiğimiz çalışmaların hiçbiri iletişim alanında gazete haberlerini konu alarak dolaylı ya da doğrudan ideoloji tartışması yürüten tezlere odaklanmamıştır. Bununla birlikte çalışmalarda ele alınan tezler belli dönemler içerisinde tamamlanan tezler araştırmalara konu olmuştur. $\mathrm{Bu}$ nedenle bu çalışma gazete haberlerini konu alan ve ideoloji tartışması yürüten yüksek lisans tezlerinin dağılımını ve değişimini ortaya koyması bakımında bütünlüklü çıkarımlar yapmaya imkân tanıyacak, bundan sonra yapılacak araştırmalara katkı sunacaktır.

\section{İnceleme Konusu Olan Yüksek Lisans Tezleri}

$\mathrm{Bu}$ çalışmanın evreni gazete haberlerini konu alan 409 yüksek lisans tezinden oluşmaktadır. Evreni belirlemek için Ulusal Tez Merkezi'nden (UTM) yararlanılmış, gelişmiş tarama seçeneğinden (https://tez.yok.gov.tr/UlusalTezMerkezi/tarama.jsp) arama yapılmıştır. Bu aramada kullanılan 27 kelime grubu şunlardır:7 "Haber-gazete”, “ideoloji-medya”, “ideoloji-haber", “ideoloji-gazete", "ideoloji-foto", “ideoloji-basın”, "gazete-içerik", "gazete-söylem”, "gazete-hegemonya”, "gazeteyanlış bilinç", "gazete-devletin ideolojik aygıtları", "gazete-foto", "gazete-camera obscura”, "haberiçerik", "haber-söylem”, "haber-hegemonya”, "haber-yanlış bilinç", "haber-devletin ideolojik aygıtları", "haber-foto", "haber-camera obscura", "basın-içerik", "basın-söylem”, "basınhegemonya", "basın-camera obscura”, "basın-yanlış bilinç", "basın-devletin ideolojik aygıtları", "basin-foto", "medya-foto".

$\mathrm{Bu}$ çalışmanın evrenine anabilim dalı penceresinden bakarsak, evren enstitülerin iletişim alanındaki anabilim dalları altında yapılan yüksek lisans tezlerini kapsamaktadır. ${ }^{8}$ Böyle bir tercih yapılmasının sebebi ise iletişim anabilim dalları dışında yapılan tezlerin merkezinde iletişimin değil yapıldığı anabilim dalındaki tarih, edebiyat ya da sosyoloji gibi alanların yer almasıdır. Bu çalışmada da amaç iletişim merkezli çalışmalar üzerine bir değerlendirme yapmak olduğu için böyle bir sınırlandırmaya

\footnotetext{
6 Bu çalışmada sadece yüksek lisans tezlerine odaklanıldığı için doktora tezlerini konu alan çalışmalara değinilmemiştir. Ancak sadece iletişim alanındaki doktora tezlerini konu olan çalışmalarında olduğunu söylemek gerekir. Örneğin, Aktaş ve Özdemir, 2006; Ateş, 2016; Çetin, Yaşin ve Sönmez, 2016; Tokgöz, 2006a, 2006b, 2015a; H. Yüksel, 2016.

7 Aramalarda tek başına medya, gazete, haber, ideoloji, basın kelimeleri kullanılmamıştır. Bunun nedeni kelimelerin taranması sonucu sırasıyla 3486, 4353, 6173, 3019, 12609 adet tez çıkmasıdır. Bu kadar kayıt arasından bir evren oluşturmanın zorluğunu gidermek için gazete-haber, gazete-söylem gibi ikili kelime grupları oluşturularak arama yapılmıştır.

8 Evreni oluşturan tezlerin anabilim dalları şöyledir: Basın ve Yayın Anabilim Dalı, Gazetecilik Anabilim Dalı, Halkla İlişkiler ve (Reklamcılık) Tanıtım Anabilim Dalı, İletişim Bilimleri Bilim Dalı, Medya ve İletişim Sistemleri Anabilim Dalı, Medya ve Kültürel Çalışmalar Anabilim Dalı, Radyo Televizyon ve (Sinema) Anabilim Dalı, İletişim ve Tasarım Anabilim Dalı, İletişim Sanatları Anabilim Dalı, İletişim ve Tasarım Anasanat Dalı/İletişim Sanatları ve Tasarım Sanat Dalı, İletişim ve Toplumsal Dönüşüm Anabilim Dalı, İletişim Yönetimi Anabilim Dalı, İletişim Yüksek Lisans (Yaşar Üniversitesi), Stratejik İletişim Yönetimi Anabilim Dalı.
} 
gidilmiştir. Bununla birlikte yapılan taramada iletişim alanı dışından yapılan ve iletişime dokunan çalışmaların başka bir araştırmaya konu olabilecek birikime sahip olduğu görülmüştür.

Çalışmanın kapsamında incelenecek tezlerin başlangıcı olarak bir tarih sınırlamasına gidilmemiştir. Bunun nedeni, tezlerdeki yaklaşımları bütünlüklü bir biçimde genel bir çerçeveden görebilmektir. ${ }^{9}$ Evrenin 2017 yılına kadar tamamlanan tezlerden oluşturulma nedeni ise bu çalışmaya başlama tarihinin 2017 yılının başı olması ve 2017 yılı içerisinde UTM'ye sürekli tez girişi yapılması nedeniyle bunların takip edilmesinin ya da evrenin güncellenmesinin zorluğudur. Ayrıca çalışmanın amaçları doğrultusunda ele aldığımızda evrenin 2017 yılına kadar yapılan tezlerden oluşması, değerlendirme için gerekli bulguyu bize sağlamaktadır ve araştırmanın amacını yerine getirmek için yeterlidir.

Şerife Çam'a göre iletişim alanındaki ideoloji tartışması, doğrudan ya da dolaylı şekilde yapılmaktadır (Çam, 2008, s. 7). Bu araştırmada da doğrudan ya da dolaylı yoldan ideoloji yaklaşımı geliştirilen çalışmalar evreni oluşturmaktadır. Bunu biraz açarsak, inceleme evrenine dahil edilen tezlerin ideoloji yaklaşımlarını incelerken ideoloji kelimesini kullanmaları şartı aranmamıştır. Örneğin, 1985 yılında Rüveyde Akyürek tarafından yapılan yüksek lisans tezindeki “... dedikodu haberleri, kadın köşeleri de okuyucuya yönelik güdüleyici bir işlev görmeye başlamıştır. Bu yüzyılda popüler kültür ürünleri ile kişiye "Sahte Özgürleşim” olanağı sunulmuştur" (Akyürek, 1985, s. iii) şeklindeki çıkarım, bize söz konusu çalışmadaki ideoloji yaklaşımı hakkında bilgi vermektedir. Basının "güdüleyici" rolüne vurgu yapılması, "sahte özgürleşim” kavramlaştırmasına gidilmesi, tezde ideoloji kelimesini kullanmadan bir ideoloji yaklaşımı ortaya koymuştur. "Türk Basınının Gelişiminde Basında Ekonomi ve Ekonomi Basını: Kavram ve Kapsam Açısından Uygulamalı Bir Çalışma” (E. Yüksel, 1996) başlıklı diğer bir örnekte ise 1980 sonrası habercilik pratiklerinin nasıl olması gerektiği sorunsallaştırılmış, ideoloji kelimesi üzerinden açık bir tartışma yapılmamıştır. Ancak ideal haber işleyişi, liberal yaklaşım içerisinden belirtilirken aslında bir ideolojik sınıflandırma ve tanımlama yapılmış, ideoloji yaklaşımı ortaya konulmuştur. Haber gerçekliği aktaran bir yapıya tanımlanmış bunun yapılması için gerekli olan ilkelere ulaşmak amacıyla bir araştırma yürütülmüştür. Verdiğimiz bu iki örnek doğrultusunda baktığımızda, haber metinlerini konu alan bir tartışmanın hangi kuramsal yaklaşımı benimserse benimsesin ideoloji kavramından kaçınması söz konusu değildir. $\mathrm{Bu}$ nedenle gazete haberlerini konu alan tezlerin hepsi evrene dâhil edilmeye çalışılmıştır. Ayrıca ideoloji kuramcilarının Karl Marx'ın sadece "camera obscura" metaforundan birçok ideoloji kavramlaştırması ve yaklaşımı türettiği de hatırlarsak doğası gereği ideoloji kavramı gazete haberlerini konu alan her çalışmayı evrenimize dâhil etme olanağını bize sunmaktadır.

Anaakım medya çalışmaları içerisinde şüphesiz ideoloji yaklaşımları bulunmaktadır. Ancak eleştirel ve anaakım paradigmalar ideoloji sorunsallaştırması noktasında birbirinden farklılaşmakta, anaakım pencereden yapılan araştırmalarda ideoloji sorunsal olarak belirlenmemektedir (Çam, 2008, s. 11). Eleştirel medya çalışmalarında ise ideoloji, toplumsal çatışmaların nasıl gösterilmediği, çarpıtıldığı ya da bu çatışmaların görmezden gelinerek nasıl bir gerçekliğin inşa edildiği noktalarından hareketle sorunsallaştırılmaktadır. Tüm bunlarla beraber bu çalışmada anaakım paradigma içerisinde yapılmış tezleri dışarda bırakmak gibi bir amaç güdülmemiştir. Bunun ilk nedeni incelenen tezlerde böyle bir ayrımın imkânsız olmasıdır. İkinci olarak liberal bir bakış açısıyla kurulmuş çalışmalarda yukarıda

\footnotetext{
9 Buradan anlaşılacağı gibi çalışmanın evreni 1982 yılında alınan kararla kurulmaya başlanan enstitülerde yapılmış tezleri kapsamaktadır. Ancak bu durum 1982 öncesi iletişimi merkezine alan lisansüstü tezin yapılmadığı anlamına gelmez. 1982 öncesi farklı fakültelerde iletişim konulu tezler (özellikle doktora) yapılmıştır.
} 
belirttiğimiz Akyürek (1985) ve E. Yüksel’in (1996) tezlerindeki gibi dolaylı ya da doğrudan ideoloji tartışması yürütülmüştür.

Daha önce belirttiğimiz gibi bu araştırmada temel amaç iki değişken (üniversite ve tezlerin tamamlanma yılları) üzerinden evrendeki tezleri değerlendirmektir. Bu ayrımda açıklanması gereken tezlerin tamamlanma yılları üzerinden nasıl dönemselleştirildiğidir. Şekil 1'de de görüldüğü üzere 1985-1997 arasındaki yıllarda yapılan tez sayısı beşin altında kaldığı için bu tarihler arası birinci dönem olarak belirlenmiştir. İkinci dönem kabul edilen 1998-2005 arasındaki yıllarda 5 ile 16 arasında çalışma tamamlanmıştır. Son dönem olan 1998-2016 yılları arasında ise teslim edilen tez sayısında yirmi ve üstünü görmek mümkündür. Tezlerin tamamlanma yıllarına göre bu dağılımı, yapılan dönemselleştirmenin temelini oluşturmaktadır.

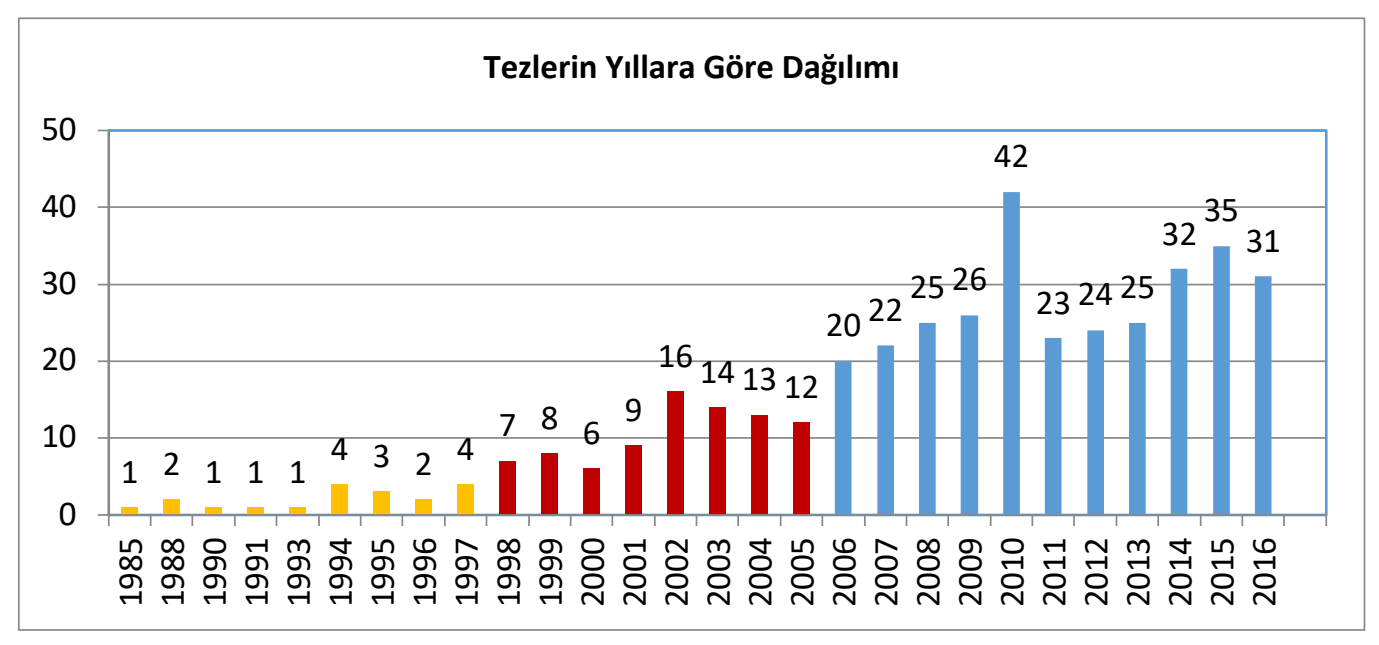

\section{Şekil 1. Tezlerin Yıllara Göre Dağılımı}

Çizilen bu çerçevede gazete haberlerini konu alan yüksek lisans tezlerinin, üniversite ve dönem başlıkları altında anabilim dallarına, ön plana çıan konularına, kuramsal yaklaşımlarına, yöntemlerine, hipotez durumlarına, inceledikleri gazetelerin kapsamına göre nasıl dağılım gösterdiği bibliyometrik yöntem ile incelenmiştir.

\section{Bibliyometrik Yöntem}

Bibliyometri kelimesi Latince ve Yunanca kökenli "biblion" ve "metricus" ya da "metricos" kelimelerinin birleşmesiyle oluşmuştur (Sengupta, 1992, s. 76). Bu kelimelerin Türkçe anlamlarına baktığımızda "biblion" kitap, "metricus" ya da "metricos" ise ölçmeye karşıllk gelmektedir.

Alan Pritchard, "istatistiksel bibliyografya"yı 1922 yılında ortaya atan ilk kişi olan Wyndham Hulme'nin, bu terimi bilimdeki sürecin nasıl işlediğinin nicel olarak analiz etmek anlamında kullandığını belirtir. Sonrasında bu tanımdan yola çıkarak istatistiksel bibliyografiyi "yazılı iletişimin ve bir disiplin gelişiminin doğası ile izlediği yolun süreçlerine, yazılı iletişimin çeşitli özeliklerinin sayımı ve analizi ile ışık tutmak" şeklinde açıklar (Pritchard, 1969, s. 348). İstatiksel bibliyografinin tam olarak tanımlayıcı olmadığını ve istatistik ya da istatistiklere ilişkin bibliyografya gibi kafa karışıklığına yol açtığını belirten Pritchard, "istatistiksel bibliyografya" yerine "bibliyometri" kavramının kullanılmasını önermiştir. Pritchard, yazısında ilk defa kullandığı bibliyometriyi, “matematiksel ve istatistiksel yöntemlerin kitap ve iletişim araçlarına uygulanması" şeklinde tanımlamıştır (1969). 1972 yılında yaptığı ikinci tanımda ise bibliyometriyi, “bilgi aktarma süreciyle 
ilgili ölçübilimi” şeklinde açıklar (Akt. Sengupta, 1992, s. 77). Pritchard, birinci tanımında bibliyometriyi bir uygulama ya da yöntem olarak görürken ikincisinde ise bilim olarak kabul etmiştir.

1969 yılından sonra farklı araştırmacılar bibliyometri ile ilgili tanımlar ${ }^{10}$ yapmışlardır (Broadus, 1987; Osareh, 1996). Bunların hepsine burada yer verme imkânı olmamakla birlikte çalışma için önemli birkaç tanıma değinmekte fayda vardır. Robert N. Broadus'a göre Joseph C. Donohue ile David Nicholas ve Maureen Ritchie'nin açıklamaları bibliyometriyi tanımlamak için kullanışlıdır (1987). Donohue, "A Bibliometric Analysis of Certain Information Science Literature" (1972) başlıklı makalesinde bibliyometriyi "kitaplar, dergi makaleleri gibi büyük bibliyografik birimlerin niceliksel analizi" olarak tanımlarken (1972, s. 313) Nicholas ve Ritchie ise bibliyometriyi "bir literatürün istatistiksel ya da niceliksel tanımı" şeklinde açıklamıştır (1978, s. 9). Bu çalışmada inceleme konusu edilen tezler Donohue'nin "büyük bibliyografik birimler" tanımına, tezler üzerine yapılan inceleme de Nicholas ve Ritchie'nin "literatürün niceliksel analizi” açıklamasına uymaktadır. Bibliyometrinin diğer bir tanımı ise Virgil P. Diodato tarafından "bilginin dağılımındaki yayın ve iletişim kalıplarını incelemek için saymadan hesaplamaya, matematiksel ve istatistiksel tekniklerin kullanıldığ bir alan" şeklinde yapılmıştır (2012, s. vii). Türkçedeki karşılığının ne olduğuna bakmak istediğimizde ise bibliyometri ya da bibliyometrik kelimelerinin, TDK sözlügünde yer almadığı görülmüştür. ${ }^{11}$

Bibliyometride temel amaç bilimsel yayın, bilgi ve iletişim aktivitelerini niceliksel olarak analiz etmektir. Ayrıca bibliyometrik çalışmalar bilimsel iletişimin sağlanmasında önemli bir role sahiptir (Osareh, 1996, s. 150-151). Bunlara ek olarak Eugene Garfield, bilim insanlarının literatüre hâkim olması amacıyla da bibliyometrik çalışma yapıldığını belirtir (Garfield, 2009, s. 175). Frederick W. Lancaster'e göre bibliyometrik çalışmalar, üretimle ilgili niceliksel analiz, literatürün kullanımı, dağılımı, gelişmesi ile literatüre ne kadar katkı yapıldığının ve literatürde güncelliğini kaybeden konuların analizini amaçlamaktadır (1991, s. 1).

Bibliyometrik çalışmalar literatürün yazarlar ya da kurumlar tarafından nasıl etkilendiğini, bunların ilişkilerini, alandaki değişimin nasıl olduğunu ve olacağını incelemek için kullanılmaktadır (Türktarhan, 2013). Ayrıca incelenen alanda, tarihsel olarak hangi konulara ağırlık verildiğinin, hangi konuların ön plana çıktığının belirlenmesi için bibliyometrik çözümleme uygun bir yöntemdir (Uşkul, 2016, s. 16). Bibliyometrik çözümleme, evrenin tamamı ya da örneklem üzerinden ilgili konunun literatürü hakkında somut bilgilerin ortaya konulmasını ve genelleme yapılmasını sağlar. Tarihsel süreçteki değerlendirmeler için uygun olan bu çözümleme yöntemi, alan ya da konunun farklı başlıklar altında zaman içerisindeki değişimlerini ortaya koymaya yardımcı olur. Gelecekte yapılacak çalışmaların eğilimine ışık tutar. Bununla birlikte alanda yapılan çalışmaların boşluklarının tespit edilmesine ve bunların doldurulmasına olanak tanır (İnceoğlu, 2014, s. 34-26).

Sengupta, bibliyometrik yöntem ile yapılan niceliksel analize, bilimin gelişimini doğru olarak yansıtmayacağı yönünde olumsuz eleştirilerin de yapıldığını belirtir. Eleştirilerin dayanak noktası ise her yayının bilginin gelişmesine aynı katkıyı yapmadığıdır (Sengupta, 1992, s. 89). İncelenen ya da karşılaştırılan her birimin sayılması, onların eşit değerlerde olduğu varsayımından hareket etmektedir. Ancak durumun böyle olmadığı açıktır. Bilginin ölçümü çabası içine girmek birçok soru işaretini ortaya çıkaracaktır. Öncelikle ölçüm için incelenecek yapıların hangilerinin ya da ölçülecek

\footnotetext{
${ }^{10}$ Bu tanımlar için bkz. Broadus, 1987; Okubo, 1997; Osareh, 1996; Sengupta, 1992.

${ }^{11}$ Son sorgulama 1.3.2019 tarihinde yapılmıştır.
} 
bilginin ne olduğu tartışılması gereken noktalardır. Bu araştırma özelinde bibliyometrinin bu sınırlılığını ele alırsak, bu çalışmadaki amacın bilgiyi ölçmekten ziyade betimlemek olduğunu belirtmek gerekir.

Bibliyometrik çözümleme uygulamada bir esneklik sunması nedeniyle farklı alanlarda yapılan çalışmalarda yöntem olarak kullanılmaktadır (Osareh, 1996, s. 152). Ancak bu bibliyometrik yöntemin sonsuz şekilde uygulanabilir olduğu anlamına gelmez. İletişim alanından bir örnek verirsek Teun Adrian van Dijk'in eleştirel söylem çözümlemesi üzerinden gidebiliriz. van Dijk, eleştirel söylem çözümlemesi için verdiği yöntemini formül şeklinde sunar. İncelenen içerikleri makro ve mikro şeklinde böler sonrasında ise bu başlıklar altında çözümlemenin nasıl yapılacağını ayrıntılandırır (Özer, 2011, s. 82-86). Bibliyometrik çözümlemede ise böyle kesinleşmiş bir formül yoktur. Çözümlemenin uygulanacağı evren amaca (kurumların, yazarların, ülkelerin üretkenliği ya da tarihsel süreçteki bilimsel yayınlarının değişiminin ya da atıfların analizi) uygun başlıklar altında ortaya konulur.

Nicholas ve Ritchie, bibliyometrik çalışmaları betimleyici ve davranışsal olmak üzere ikiye ayırır. Betimleyici çalışmalar bir alanın özellikleri ya da yapısını ele alırken, sadece güncel çalışmaları değil geçmişini de değerlendirir ve bugüne nasıl gelindiğini anlamaya çalışır. Davranışsal çalışmalarda ise alan ya da konuya ait literatürü oluşturan bileşenler (yazarlar, çalışmalar, konular vb.) arasındaki ilişkileri incelemektedir (Nicholas ve Ritchie, 1978, s. 9-10). Nicholas ve Ritchie’nin yaptı̆̆1 sınıflandırmaya göre bu çalışma betimleyici bibliyometrik bir araştırmadır. Betimsel başlığını biraz daha açarsak Nicholas ve Ritchie betimleyici bibliyometrik çalışmalarda inceleme konusu olabilecek yapıları şöyle sıralar: (1978, s. 10):

a. "Bilginin ïretilmesi ve iletilmesinden sorumlu kurumlar:"12 Üniversiteler, araştırma kuruluşları, bazı devlet kurumları vb. bu maddeye örnek gösterilebilir. Bu çalışmada da bibliyometrik incelemenin iki ayağından (tezlerin üniversitelere ve yıllara göre dağılımı) birini, ideoloji konulu tezlerin kurumlara yani “üniversitelere” göre dağılımı oluşturmaktadır.

\section{b. "Dağıtım biçimi (dergi, monografi vb)"}

c. "İletişim yapıları (makale, mektup, vb):" Çalışmanın evrenini oluşturan ve iletişim anabilim dalları altında yapılmış ideoloji konulu tezler hem "dağıtım biçimi” hem de "iletişim yapıları" maddelerinin kapsamına girmektedir.

d. “Aktarılan bilginin özelliği-konu ve dil yapısı:” Çalışmada incelenen tezlerdeki ideoloji yaklaşımının hangi konular üzerinden ele alındığını gösteren tablolar bu başlığa örnek verilebilir.

e. "Bilginin ulaşma zamanı ve sıklı̆̆ı:" Bu çalışmada evrendeki tezlerin “üniversiteler" ve “dönemler" olmak üzere iki ana başlık ve bunların alt başlıkları altında dağılımının nicel olarak ortaya konulduğunu hatırlarsak "dönemler" altındaki başlıklarda verilen tablolar bu maddeye işaret etmektedir.

f. “Aktarılan bilgi miktarı:” Tam olarak bilgi miktarı şeklinde bir tanımlama ve değerlendirme bu çalışmada bulunmamaktadır. Nitekim "bilginin miktarı” şeklindeki bir kavramlaştırma tartışmalıdır

\footnotetext{
${ }^{12}$ Maddelerin ve yöntemin bu araştırma bağlamında daha iyi anlaşılabilmesi için yazarların sıraladığı başlıklara örnekler verilmiştir.
} 
ve bu araştırmada bilginin miktarını belirlemek gibi bir gayret içine girilmemiştir. Ancak üniversitelere ve yılara göre tez sayılarının dağılımları ve değişimleri çalışmada ortaya koyan veriler bu maddeye en yakın örnek olabilir.

g. “Coğrafi kökeni:” "Türkiye'de yapılan yüksek lisans tezleri” şeklinde çalışmanın evreninin belirlenmiş olması, coğrafi kökenine karşılık gelmektedir. Ayrıca üniversiteler özelinde yapılan nicel analiz, ideoloji kavramına coğrafi olarak nasıl yaklaşıldığını bize göstermektedir.

\section{Gazete Haberlerini Konu Alan Tezlerin Yıllara ve Üniversitelere Göre Dağılımları}

Çalışmanın bu bölümünde gazete haberlerini konu alan yüksek lisans tezlerinin bibliyometrik çözümlemesi yapılmıştır. Yöntem kısmında da belirttiğimiz gibi bibliyometrik analizde tezlerin yapıldığı üniversite ve yıl olmak üzere iki değişken temel alınmıştır. Bu iki değişken altında çalışmaların anabilim dallarına, konularına, kuramsal yaklaşımlarına, yöntemlerine, hipotez durumlarına ve inceledikleri gazetelerin kapsamına göre dağılımları ${ }^{13}$ tablolar halinde verilmiştir.

\section{Tezlerin Üniversitelere ${ }^{14}$ Göre Dağılımları}

Evrendeki çalışmaların bibliyometrik çözümlemesinde öncelikle dağılımlarına ve üniversitelerde gazete haberlerini konu alan ilk çalışmanın yapılma tarihine bakmak, diğer tabloları daha sağlıklı değerlendirmemizi sağlayacaktır. ${ }^{15}$

\begin{tabular}{|l|c|c|c|c|c|c|c|}
\hline \multicolumn{2}{|c|}{$\begin{array}{c}\text { Tablo 1: Üniversitelerde Tamamlanan Tez Sayıları ve Gazete } \\
\text { Haberlerini Konu Alan İlk Tezlerin Tes lim Tarihleri }\end{array}$} \\
\hline $\begin{array}{c}\text { Tezlerin Yapıldığı } \\
\text { Üniversiteler }\end{array}$ & Toplam & $\begin{array}{c}\text { Tamamlan } \\
\text { dığı Tarih }\end{array}$ & $\begin{array}{c}\text { Tezlerin Yapıldığı } \\
\text { Üniversiteler }\end{array}$ & \multicolumn{2}{c|}{ Toplam } & $\begin{array}{c}\text { Tamamlan } \\
\text { diğı Tarih }\end{array}$ \\
\hline Akdeniz Üni. & 7 & $2 \%$ & 2015 & İstanbul Arel Üni. & 6 & $1 \%$ & 2013 \\
\hline Anadolu Üni. & 41 & $10 \%$ & 1985 & İstanbul Aydın Üni. & 1 & $0 \%$ & 2013 \\
\hline Ankara Üni. & 62 & $15 \%$ & 1990 & İstanbul Bilgi Üni. & 3 & $1 \%$ & 2011 \\
\hline Atatürk Üni. & 15 & $4 \%$ & 2002 & İstanbul Kültür Üni. & 1 & $0 \%$ & 2012 \\
\hline Baş kent Üni. & 2 & $0 \%$ & 2011 & İstanbul Ticaret Üni. & 2 & $0 \%$ & 2013 \\
\hline Beykent Üni. & 1 & $0 \%$ & 2016 & İstanbul Üni. & 41 & $10 \%$ & 1986 \\
\hline Ege Üni. & 28 & $7 \%$ & 1991 & Kadir Has Üni. & 2 & $0 \%$ & 2012 \\
\hline Erciyes Üni. & 17 & $4 \%$ & 2006 & Kocaeli Üni. & 18 & $4 \%$ & 2002 \\
\hline Furat Üni. & 5 & $1 \%$ & 2006 & Marmara Üni. & 43 & $11 \%$ & 1998 \\
\hline Galatas aray Üni. & 7 & $2 \%$ & 2007 & Orta Doğu Teknik Üni. & 7 & $2 \%$ & 2006 \\
\hline Gazi Üni. & 66 & $16 \%$ & 1993 & Selçuk Üni. & 23 & $6 \%$ & 1999 \\
\hline Gaziantep Üni. & 2 & $0 \%$ & 2014 & Yaşar Üni. & 2 & $0 \%$ & 2014 \\
\hline Girne Amerikan Üni. & 1 & $0 \%$ & 2014 & Yeditepe Üni. & 2 & $0 \%$ & 2009 \\
\hline Hacettepe Üni. & 2 & $0 \%$ & 2010 & Yeni Yüzyıl Üni. & 1 & $0 \%$ & 2015 \\
\hline İhs an D. Bilkent Üni. & 1 & $0 \%$ & 2016 & Toplam Tez Sayısı & 409 \\
\hline
\end{tabular}

\footnotetext{
${ }^{13} \mathrm{Bu}$ bölümde seçilen değerlendirme başlıkları, yapılan sınıflandırmalar ve ortaya konulan nicel veriler pozitivist bir bakış açısı içerisinden ampirik bir iddia taşımamaktadır. Tablolarda seçilen başlıklarda ve tezlerin bu başlıklar altına dağıtılmasında araştırmacının sübjektif yaklaşımlarının olduğu göz önünde bulundurulmalıdır.

14 Üniversitelere göre dağılımlarından kasıt, sözü edilen üniversitelerdeki iletişim anabilim dalları altında yapılmış tezlerdir.

${ }^{15}$ Tablolarda yüzdeliklerin verilmesinde ondalıklı sayı kullanılmadığı için 0,5 altındaki yüzdeler 0'a üzerindeki yüzdeler de 1'e tamamlanmıştır. $\mathrm{Bu}$ durum tüm tablolar için geçerlidir.
} 
Gazete haberlerini konu alan yüksek lisans tezlerinin üniversitelere göre dağılımlarını ele aldığımızda Gazi $^{16}$ (yüzde 16), Ankara (yüzde 15), İstanbul (yüzde 10), Marmara (yüzde 11), Anadolu (yüzde 10), Ege (yüzde 7) ve Selçuk (yüzde 6) Üniversitelerinde, evrendeki çalışmaların yüzde 75’inin tamamlanmış olduğunu Tablo 1'de görmekteyiz. Bunların içinde ise Ankara (62 tez) ile Gazi (66 tez) Üniversiteleri ön plana çıkmaktadır. Toplamda yedi üniversitede yapılan tezlerin, evrenin yüzde 75'inin oluşturmasının nedeni, iletişim alanındaki lisansüstü eğitimin öncelikle bu üniversitelerde başlamasıdır. ${ }^{17}$

Tablo 1'deki diğer veri olan gazete haberlerini konu alan tezlerin yapılmaya başlandığ tarihlere göre bakarsak ilk çalışmalar Anadolu (1985) ve İstanbul (1986) Üniversitelerinde yapılmıştır. Ancak Ankara (1990), Gazi (1993), ve Marmara (1998) Üniversitelerinde gazete haberlerini konu alan araştırmalar daha sonraki tarihlerde yapılmaya başlanmış olmasına rağmen Anadolu ve İstanbul Üniversitesi'nden daha fazla tez bu üç üniversitede tamamlanmıştır. Gazete haberlerinin yoğun olarak konu edildiği üniversitelerin dışındakilere baktığımızda, Atatürk (15 tez), Erciyes (17 tez) ve Kocaeli (18 tez) Üniversitelerinde sayıca daha fazla çalışmanın teslim edildiğini Tablo 1'de görebiliriz. Sonrasında ise Akdeniz, Fırat, Galatasaray, Arel ve Orta Doğu Teknik (ODTÜ) Üniversitelerinde 5 ile 7 arasında tez teslim edilmiştir. Burada dikkat çeken ise Akdeniz Üniversitesi'dir. Akdeniz Üniversitesi'nde gazete haberlerini konulaştıran çalışmaların 2015 yılında ilk olarak yapılmasına rağmen iki yılda toplam 7 tez tamamlanmıştır. Bu da bize Akdeniz Üniversitesi'nde yıl başına 3,5 çalışmanın düştüğünü gösterir. Diğer üniversiteler ile kıyasladığımızda Akdeniz en yüksek orana sahip olarak karşımıza çıkmaktadır. Arakasından gelen ve en yüksek ikinci tez ortalamasına sahip Gazi'de de yıl başına düşen tez sayısı ise 2,9'dur.

Evrene dâhil edilen çalışmaların başlangıcı olarak bir sınır koymazken bitiş tarihi olarak 2016 yılının sonunu seçtiğimizi ve nedenini çalışmanın evreni bölümünde belirtmiştik. 2016 yılının sonuna kadar tamamlanan çalışmaları da tarihsel olarak üç döneme ayırmıştık. Yaptığımız dönemselleştirme bağlamında üniversitelerde tamamlanan tezlerin yüzde 5’i (19 tez) birinci dönemde, yüzde 21'i (85 tez) ikinci dönemde, yüzde 75 ’ de (305 tez) üçüncü dönemde teslim edilmiştir (Tablo 2). ${ }^{18}$ Üniversiteler özelinde ele aldığımızda Tablo 2'de, Anadolu, Ankara, Ege, Gazi ve İstanbul Üniversitesi'nde üç dönemde de gazete haberlerini konu alan çalışmaların yapıldığını görmek mümkündür. Atatürk, Kocaeli, Marmara, Selçuk Üniversiteleri’nde ise ikinci ve üçüncü dönemlerde

\footnotetext{
${ }^{16}$ Tezin bundan sonraki bölümlerinde bahsettiğimiz Gazi Üniversitesi İletişim Fakültesi çıkarılan "Yükseköğretim Kanunu ile Bazı Kanun ve Kanun Hükmünde Kararnamelerde Değişiklik Yapılmasına Dair Kanun” (7141 Sayılı) ile Mayıs 2018 tarihinde Gazi Üniversitesi'nden ayrılarak yeni kurulan Ankara Hacı Bayram Veli Üniversitesi'ne bağlanmıştır (Resmî Gazete, 18.05.2018). Ancak tezlerin tamamlandığı dönemde İletişim Fakültesi'nin Gazi Üniversitesi'ne bağlı olması nedeniyle çalışmada Gazi Üniversitesi şeklinde ele alınmıştır.

17 Türkiye'deki iletişim çatısı altında ilk lisansüstü eğitim, Eskişehir İktisadi ve Ticari İlimler Akademisi Televizyon ile Öğretim ve Eğitim Fakültesi'nde 1979 yılında başlamıştır (Resmi Gazete, 13 Aralık 1979). Bu Fakülte'nin adı kısa bir süre sonra (Mayıs 1980) İletişim Bilimleri Fakültesi olarak değiştirilmiştir. Sonrasında ise 1982 yılında sosyal bilimler enstitülerinin kurulmasıyla birlikte diğer üniversitelerde de iletişim anabilim dalları altında lisansüstü çalışmalar başlamıştır. 1983 yılında İstanbul ve Marmara Üniversitelerinde yüksek lisans ve doktora, 1984 yılında Gazi ve Anadolu Üniversitesi, 1986 yılında Ankara ve Ege Üniversitesi'nde yüksek lisans programları, iletişim alanında lisansüstü eğitim amacıyla öğrenci kabul etmeye başlamıştır (Tokgöz, 2003, s. 14-26; 2006a, s. 40).

${ }^{18} \mathrm{Bu}$ bölümde üniversiteler bağlamında bir incelme yapılacağı için Tablo 1 dışındaki oranlamaların bir başlık altındaki tez sayısının üniversitede yapılan toplam tez sayısına oranını gösterecek şekilde hesaplandığını belirtmek gerekir. Örneğin gazetecilik anabilim dalı altında Akdeniz Üniversitesi'nde yapılan 5 tezin tüm gazetecilik anabilim dalları altında yapılan tezlere oranı değil, Akdeniz'de yapılan toplam tez sayısına oranı verilmiştir. Oranlamanın bu şekilde yapılmasının nedeni çalışmanın amacına uygun olarak üniversiteler bağlamında bir değerlendirme yapmaktır. Tablolardaki toplam satır ve sütunlarına da kısaca değinecek olursak, toplam sütununda üniversitelerde yapılan toplam tez sayısına, toplam satırlarında ise incelenen başlık altında yapılmış çalışmaların toplam sayısı ve bu sayının evrene olan oranına yer verilmiştir.
} 
tez yapılmıştır. Geriye kalan üniversitelerde ise 2006 sonrası yani sadece üçüncü dönemde gazete haberlerini konu alan tezler teslim edilmiştir.

1983-1986 yılları arasında İstanbul, Marmara, Gazi, Anadolu, Ankara ve Ege Üniversitelerinde lisansüstü eğitimin başlamış olduğunu hatırlasak lisansüstü eğitime başlayan altı üniversite arasında sadece Marmara Üniversitesi'nde birinci dönemde gazete haberlerini konu alan çalışma yapılmamıştır. Marmara Üniversitesi'nde ilk gazete haberlerini konu alan yüksek lisans tezinin teslim tarihi 1998 yılı olmuştur (Tablo 1). Bu da bize iletişimde lisansüstü eğitimin başladığı Marmara Üniversitesi dışındaki beş üniversitede başından itibaren gazete haberleri üzerinden ideoloji tartışmasının yapıldı̆̆ının göstermektedir.

Tablo 2: Tezlerin Üniversitelere ve Dönemlere Göre Dağılımlan

\begin{tabular}{|c|c|c|c|c|c|c|c|}
\hline \multirow{3}{*}{\begin{tabular}{|l}
$\begin{array}{c}\text { Tezlerin Yapıldığı } \\
\text { Üniversiteler }\end{array}$ \\
Akdeniz Üni.
\end{tabular}} & \multicolumn{6}{|c|}{ Dönemler } & \multirow{3}{*}{$\begin{array}{r}\text { Top } \\
\text { lam } \\
7 \\
7\end{array}$} \\
\hline & \multicolumn{2}{|c|}{$\begin{array}{c}\text { 1. Dönem } \\
\text { 1985-1997 }\end{array}$} & \multicolumn{2}{|c|}{$\begin{array}{c}\text { 2. Dönem } \\
\text { 1998-2005 }\end{array}$} & \multicolumn{2}{|c|}{$\begin{array}{l}\text { 3. Dönem } \\
\text { 2006-2016 }\end{array}$} & \\
\hline & & & & & 7 & $100 \%$ & \\
\hline Anadolu Üni. & 7 & $17 \%$ & 12 & $29 \%$ & 22 & $54 \%$ & 41 \\
\hline Ankara Üni. & 3 & $5 \%$ & 24 & $39 \%$ & 35 & $56 \%$ & 62 \\
\hline Atatürk Üni. & & & 1 & $7 \%$ & 14 & $93 \%$ & 15 \\
\hline Baş kent Üni. & & & & & 2 & $100 \%$ & 2 \\
\hline Beykent Üni. & & & & & 1 & $100 \%$ & 1 \\
\hline Ege Üni. & 1 & $4 \%$ & 17 & $61 \%$ & 10 & $36 \%$ & 28 \\
\hline Erciyes Üni. & & & & & 17 & $100 \%$ & 17 \\
\hline Firat Üni. & & & & & 5 & $100 \%$ & 5 \\
\hline Galatas aray Üni. & & & & & 7 & $100 \%$ & 7 \\
\hline Gazi Üni. & 7 & $11 \%$ & 13 & $20 \%$ & 46 & $70 \%$ & 66 \\
\hline Gaziantep Üni. & & & & & 2 & $100 \%$ & 2 \\
\hline Girne Amerikan Üni. & & & & & 1 & $100 \%$ & 1 \\
\hline Hacettepe Üni. & & & & & 2 & $100 \%$ & 2 \\
\hline İhs an D. Bilkent Üni. & & & & & 1 & $100 \%$ & 1 \\
\hline İs tanbul Arel Üni. & & & & & 6 & $100 \%$ & 6 \\
\hline İstanbul Aydın Üni. & & & & & 1 & $100 \%$ & 1 \\
\hline İs tanbul Bilgi Üni. & & & & & 3 & $100 \%$ & 3 \\
\hline İs tanbul Kültür Üni. & & & & & 1 & $100 \%$ & 1 \\
\hline İs tanbul Ticaret Üni. & & & & & 2 & $100 \%$ & 2 \\
\hline İs tanbul Üni. & 1 & $2 \%$ & 6 & $15 \%$ & 34 & $83 \%$ & 41 \\
\hline Kadir Has Üni. & & & & & 2 & $100 \%$ & 2 \\
\hline Kocaeli Üni. & & & 5 & $28 \%$ & 13 & $72 \%$ & 18 \\
\hline Marmara Üni. & & & 4 & $9 \%$ & 39 & $91 \%$ & 43 \\
\hline Orta Doğu Teknik Üni. & & & & & 7 & $100 \%$ & 7 \\
\hline Selçuk Üni. & & & 3 & $13 \%$ & 20 & $87 \%$ & 23 \\
\hline Yaşar Üni. & & & & & 2 & $100 \%$ & 2 \\
\hline Yeditepe Üni. & & & & & 2 & $100 \%$ & 2 \\
\hline Yeni Yüzyıl Üni. & & & & & 1 & $100 \%$ & 1 \\
\hline Toplam & 19 & $5 \%$ & 85 & $21 \%$ & 305 & $75 \%$ & 409 \\
\hline
\end{tabular}

Tablo 2'ye genel olarak baktığımızda gazete haberlerini konu alan ve ideolojiyi tartışan çalışmaların -Ege Üniversitesi'nde üçüncü dönem dışında- her dönem artarak devam ettiğini belirtmek gerekir. Üç dönemde toplam tamamlanan tez sayısı ise sırasıyla 19, 85, 305 olmuştur. Teslim edilen tez sayısındaki değişime bakarsak birinci döneme göre ikinci dönemde 4,4 ve ikinci döneme göre üçüncü dönemde de 3,5 kat artış olmuştur.

Tezlerin anabilim dallarına göre dağılımlarına baktığımızda en fazla çalışmanın yüzde 50 ile gazetecilik anabilim dallarında yapıldığını Tablo 3’te görebiliriz. Sonrasında ise sırasıyla halkla 
ilişkiler ve tanıtım (yüzde 11), radyo televizyon (ve sinema) ${ }^{19}$ (yüzde 9), iletişim bilimleri (yüzde 7), basın ve yayın ${ }^{20}$ (yüzde 6) ve diğer (yüzde 5) anabilim dallarında çalışmalar tamamlanmıştır. Burada dikkat edilmesi gereken nokta gazete haberleri üzerine yapılmış yüksek lisans çalışmalarından oluşan evrene halkla ilişkiler ve tanıtım ile radyo televizyon (ve sinema) anabilim dallarında yapılmış tezlerin de dâhil olmasıdır. Özelikle gazetecilikten sonra en fazla tezin (44 tez) halkla ilişkiler ve tanıtım anabilim dallarında yapılması önemlidir.

\begin{tabular}{|c|c|c|c|c|c|c|c|c|c|c|c|c|c|c|c|}
\hline \multicolumn{16}{|c|}{ Tablo 3: Tezlerin Üniversitelere ve Anabilim Dallarma Göre Dağılımlari } \\
\hline \multirow{3}{*}{$\begin{array}{l}\text { Tezlerin Yapıldh ğı } \\
\text { Üniversiteler }\end{array}$} & \multicolumn{14}{|c|}{ Anabilim Dalları } & \multirow{3}{*}{\begin{tabular}{|c|} 
Top \\
1 am \\
7 \\
\end{tabular}} \\
\hline & \multicolumn{2}{|c|}{$\begin{array}{l}\text { Basin } \\
\text { Yayin }\end{array}$} & \multicolumn{2}{|c|}{ Gazetecilik } & \multicolumn{2}{|c|}{$\begin{array}{c}\text { Halkla } \\
\text { Hisskiler } \\
\text { ve Tanitim }\end{array}$} & \multicolumn{2}{|c|}{$\begin{array}{c}\text { iletişim } \\
\text { Bilimleri }\end{array}$} & \multicolumn{2}{|c|}{$\begin{array}{c}\text { Radyo } \\
\text { Televizyo } \\
\text { n (ve } \\
\text { Sinema) } \\
\end{array}$} & \multicolumn{2}{|c|}{$\begin{array}{c}\text { Diğer } \\
\text { Anabilim } \\
\text { Dalları }\end{array}$} & \multicolumn{2}{|c|}{$\begin{array}{l}\text { Değerlend } \\
\text { irilemeyen }\end{array}$} & \\
\hline & & & 5 & $71 \%$ & 1 & $14 \%$ & & & 1 & $14 \%$ & & & & & \\
\hline Anadolu Üni. & 25 & $61 \%$ & & & 2 & $5 \%$ & 2 & $5 \%$ & & & & & 12 & $29 \%$ & 41 \\
\hline Ankara Üni. & & & 31 & $50 \%$ & 16 & $26 \%$ & & & 4 & $6 \%$ & & & 11 & $18 \%$ & 62 \\
\hline Atatürk Üni. & & & 12 & $80 \%$ & & & & & 3 & $20 \%$ & & & & & 15 \\
\hline Baş kent Üni. & & & & & 2 & $100 \%$ & & & & & & & & & 2 \\
\hline Beykent Üni. & & & & & & & & & & & 1 & $100 \%$ & & & $\mathbf{1}$ \\
\hline Fge Üni. & & & 17 & $61 \%$ & & & & & 5 & $18 \%$ & & & 6 & $21 \%$ & 28 \\
\hline Erciyes Üni. & & & 12 & $71 \%$ & 3 & $18 \%$ & & & 2 & $12 \%$ & & & & & 17 \\
\hline Firat Üni. & & & & & & & 4 & $80 \%$ & 1 & $20 \%$ & & & & & 5 \\
\hline Galatas aray Üni. & & & & & & & 1 & $14 \%$ & 5 & $71 \%$ & & & 1 & $14 \%$ & 7 \\
\hline Gazi Üni. & & & 49 & $74 \%$ & 9 & $14 \%$ & & & 2 & $3 \%$ & & & 6 & $9 \%$ & 66 \\
\hline Gaziantep Üni. & & & & & & & 2 & $100 \%$ & & & & & & & 2 \\
\hline Girne Amerikan Üni. & & & & & & & & & & & & & 1 & $100 \%$ & $\mathbf{1}$ \\
\hline Hacettepe Üni. & & & & & & & 2 & $100 \%$ & & & & & & & 2 \\
\hline Ihs an D. Bilkent Üni. & & & & & & & & & & & & & 1 & $100 \%$ & $\mathbf{1}$ \\
\hline İs tanbul Arel Üni. & & & & & & & & & & & 6 & $100 \%$ & & & 6 \\
\hline İstanbul Ayden Üni. & & & & & 1 & $100 \%$ & & & & & & & & & $\mathbf{1}$ \\
\hline iss tanbul Bilgi Üni. & & & & & & & & & & & 3 & $100 \%$ & & & 3 \\
\hline Ístanbul Kültür Üni. & & & & & & & & & & & 1 & $100 \%$ & & & $\mathbf{1}$ \\
\hline İs tanbul Ticaret Üni. & & & & & & & & & & & 2 & $100 \%$ & & & 2 \\
\hline İs tanbul Üni. & & & 33 & $80 \%$ & 3 & $7 \%$ & & & 2 & $5 \%$ & & & 3 & $7 \%$ & 41 \\
\hline Kadir Has Üni. & & & & & & & 2 & $100 \%$ & & & & & & & 2 \\
\hline Kocaeli Üni. & & & 3 & $17 \%$ & 3 & $17 \%$ & 8 & $44 \%$ & & & & & 4 & $22 \%$ & 18 \\
\hline Marmara Üni. & & & 24 & $56 \%$ & 3 & $7 \%$ & 5 & $12 \%$ & 7 & $16 \%$ & & & 4 & $9 \%$ & 43 \\
\hline Orta Doğu Teknik Üni. & & & & & & & & & & & 7 & $100 \%$ & & & 7 \\
\hline Selçuk Üni. & & & 19 & $83 \%$ & 1 & $4 \%$ & & & 2 & $9 \%$ & & & 1 & $4 \%$ & 23 \\
\hline Yaş ar Üni. & & & & & & & 2 & $100 \%$ & & & & & & & 2 \\
\hline Yeditepe Üni. & & & & & & & & & 2 & $100 \%$ & & & & & 2 \\
\hline Yeni Yüzyıl Üni. & & & & & & & & & & & 1 & $100 \%$ & & & $\mathbf{1}$ \\
\hline Toplam & 25 & $6 \%$ & 205 & $50 \%$ & 44 & $11 \%$ & 28 & $7 \%$ & 36 & $9 \%$ & 21 & $5 \%$ & 50 & $12 \%$ & \#\# \\
\hline
\end{tabular}

Halkla ilişkiler ve tanıtım anabilim dalı özelinde en fazla tez Ankara (16 tez) ve Gazi (9 tez) Üniversiteleri'nde yapılmıştır. Radyo televizyon (ve sinema) anabilim dalında ise Marmara Üniversitesi'nde (7 tez) diğer üniversitelere göre daha fazla tez tamamlanmıştır. Tablo 3'deki iletişim bilimleri anabilim dalında en çok çalışmanın Kocaeli Üniversitesi’nde (8 tez) yapıldığını söyleyebiliriz. Gazetecilik anabilim dalında ise gazete haberini konu alan en fazla tez Ankara (31 tez) ve Gazi (49 tez) Üniversitelerinde teslim edilmiştir. Diğer anabilim dalları ${ }^{21}$ başlığı altında yapılan çalışmalara değinirsek özellikle Arel Üniversitesi ve ODTÜ'deki 13 çalışmanın medya ve kültürel çalışmalar anabilim dalı altında yapıldığını belirtmek gerekir.

Üniversitelerde tamamlanan tezlerin anabilim dallarındaki çeşitliliği noktasında Marmara Üniversitesi dört anabilim dalında [gazetecilik, halkla ilişkiler ve tanıtım, iletişim bilimleri ve radyo televizyon (ve sinema)] tez yapılan tek üniversite olmuştur.

\footnotetext{
${ }^{19}$ Radyo televizyon, radyo televizyon ve sinema anabilim dallarında yapılan tezler buraya dâhil edilmiştir.

${ }^{20}$ Anadolu Üniversitesi’nde bulunan Basın Yayın Anabilim Dalı, gazetecilik anabilim dalına denk kabul edilmektedir.

${ }^{21}$ Diğer anabilim dalları ise şöyledir: Medya ve İletişim Sistemleri Anabilim Dalı, İletişim ve Tasarım Anabilim Dalı, İletişim Sanatları Anabilim Dalı, İletişim ve Tasarım Anasanat Dalı / İletişim Sanatları ve Tasarım Sanat Dalı, İletişim ve Toplumsal Dönüşüm Anabilim Dalı, İletişim Yönetimi Anabilim Dalı, İletişim Yüksek Lisans (Yaşar Üniversitesi), Stratejik İletişim Yönetimi Anabilim Dalı
} 
Evrendeki çalışmaları konuları ${ }^{22}$ bağlamında ele aldığımızda ideolojinin ağırlıklı olarak güncel siyaset [siyasi kişiler ya da olaylar (182 tez)] üzerinden çözümlendiğini Tablo 4'de görebiliriz. Sonrasında ise sırasıyla kimlik (53 tez), şiddet (43 tez) ve toplumsal cinsiyet (31 tez) konularında önemli miktarda çalışma yapılmıştır. Çevre (11 tez), kültür (10 tez) ve spor (8 tez) konuları ise en az irdelenen konular olmuştur. $\mathrm{Bu}$ nedenle yeni yapılacak çalışmalarda bu konulara yoğunlaşma ihtiyacı olduğu söylenebilir.

\begin{tabular}{|c|c|c|c|c|c|c|c|c|c|c|c|c|c|c|c|c|c|c|c|c|c|c|c|}
\hline & & Tablo & 4: 1 & ezleri & $n$ Ü̈ & niver & itel & ere $\mathbf{v}$ & ÖI & n Plan & a Ç & Ikan & Kon & ulan & a $\mathbf{c}$ & Göre & )ăg & lımla & & & & & \\
\hline & & & & & & & & & & & Ko & nular & & & & & & & & & & & \\
\hline $\begin{array}{l}\text { Tezlerın Yapildigı } \\
\text { Üniversite }\end{array}$ & $\begin{array}{l}\text { Gü } \\
\text { Siy }\end{array}$ & $\begin{array}{l}\text { incel } \\
\text { yaset }\end{array}$ & $\begin{array}{r}\text { Top } \\
\text { Ci }\end{array}$ & $\begin{array}{l}\text { umsal } \\
\text { siyet }\end{array}$ & & mlik & Ek & nomi & & evre & & ğlık & & iltür & & por & & iddet & & iğer & $\begin{array}{l}\text { Değ } \\
\text { rile }\end{array}$ & $\begin{array}{l}\text { rlendi } \\
\text { meyen }\end{array}$ & $\begin{array}{c}10 p l a \\
\text { m }\end{array}$ \\
\hline Akdeniz Üni. & 5 & $71 \%$ & & & 1 & $14 \%$ & & & & & & & & & & & 1 & $14 \%$ & & & & & 7 \\
\hline Anadolu Üni. & 12 & $29 \%$ & 4 & $10 \%$ & 1 & $2 \%$ & 3 & $7 \%$ & & & 3 & $7 \%$ & 1 & $2 \%$ & 3 & $9 \%$ & 3 & $7 \%$ & 10 & $24 \%$ & 1 & $2 \%$ & 41 \\
\hline Ankara Üni. & 35 & $56 \%$ & 2 & $3 \%$ & 10 & $16 \%$ & 6 & $10 \%$ & 1 & $2 \%$ & & & & & & & 6 & $10 \%$ & 2 & $3 \%$ & & & 62 \\
\hline Atatürk Üni. & 6 & $40 \%$ & 2 & $13 \%$ & 3 & $20 \%$ & & & & & & & & & & & 4 & $27 \%$ & & & & & 15 \\
\hline Baș kent Üni. & 2 & $100 \%$ & & & & & & & & & & & & & & & & & & & & & 2 \\
\hline Beykent Üni. & & & & & & & & & & & & & & & & & & & 1 & $100 \%$ & & & 1 \\
\hline Ege Üni. & 7 & $25 \%$ & 3 & $11 \%$ & 2 & $7 \%$ & 1 & $4 \%$ & 4 & $14 \%$ & 1 & $4 \%$ & 3 & $11 \%$ & & & 3 & $11 \%$ & 4 & $14 \%$ & & & 28 \\
\hline Erciyes Üni. & 6 & $35 \%$ & 2 & $12 \%$ & 4 & $24 \%$ & & & 1 & $6 \%$ & 1 & $6 \%$ & & & & & 1 & $6 \%$ & 2 & $12 \%$ & & & 17 \\
\hline \begin{tabular}{|l|} 
Firat Üni. \\
\end{tabular} & 3 & $60 \%$ & & & & & & & & & 1 & $20 \%$ & & & & & 1 & $20 \%$ & & & & & 5 \\
\hline Galatas aray Üni. & 4 & $57 \%$ & & & 1 & $14 \%$ & & & & & & & & & & & 2 & $29 \%$ & & & & & 7 \\
\hline Gazi Üni. & 38 & $58 \%$ & 2 & $3 \%$ & 6 & $9 \%$ & 4 & $6 \%$ & 1 & $2 \%$ & 3 & $5 \%$ & & & & & 8 & $12 \%$ & 4 & $6 \%$ & & & 66 \\
\hline Gaziantep Üni. & & & 1 & $50 \%$ & 1 & $50 \%$ & & & & & & & & & & & & & & & & & $\mathbf{2}$ \\
\hline Girne Amerikan Üni. & & & & & 1 & $100 \%$ & & & & & & & & & & & & & & & & & 1 \\
\hline Hacettepe Üni. & 1 & $50 \%$ & & & & & 1 & $50 \%$ & & & & & & & & & & & & & & & 2 \\
\hline İhsan D. Bilkent Üni. & & & & & & & & & 1 & $100 \%$ & & & & & & & & & & & & & 1 \\
\hline İstanbul Arel Üni. & 1 & $17 \%$ & & & 4 & $67 \%$ & & & & & & & & & & & & & 1 & $17 \%$ & & & 6 \\
\hline İstanbul Aydın Üni. & & & & & & & & & & & & & & & & & & & 1 & & & & 1 \\
\hline İstanbul Bilgi Üni. & 2 & $67 \%$ & & & & & 1 & $33 \%$ & & & & & & & & & & & & & & & 3 \\
\hline İstanbul Külttür Üni. & & & & & & & & & & & & & & & & & 1 & $100 \%$ & & & & & 1 \\
\hline İstanbul Ticaret Üni. & 2 & $100 \%$ & & & & & & & & & & & & & & & & & & & & & 2 \\
\hline İstanbul Üni. & 16 & $39 \%$ & & & 8 & $20 \%$ & & & 2 & $5 \%$ & 1 & $2 \%$ & 2 & $5 \%$ & 3 & $9 \%$ & 5 & $12 \%$ & 2 & $5 \%$ & 2 & $5 \%$ & 41 \\
\hline Kadir Has Üni. & & & 1 & $50 \%$ & & & & & & & & & & & & & 1 & $50 \%$ & & & & & 2 \\
\hline \begin{tabular}{|l|} 
Kocaeli Üni. \\
\end{tabular} & 9 & $50 \%$ & & & 4 & $22 \%$ & & & & & 1 & $6 \%$ & 1 & $6 \%$ & & & 3 & $17 \%$ & & & & & 18 \\
\hline \begin{tabular}{|l|} 
Marmara Üni. \\
\end{tabular} & 20 & $47 \%$ & 7 & $16 \%$ & 3 & $7 \%$ & 3 & $7 \%$ & 1 & $2 \%$ & 1 & $2 \%$ & 1 & $2 \%$ & 2 & $6 \%$ & 3 & $7 \%$ & 2 & $5 \%$ & & & 43 \\
\hline Orta Doğu Teknik Üni. & 1 & $14 \%$ & 2 & $29 \%$ & 2 & $29 \%$ & 2 & $29 \%$ & & & & & & & & & & & & & & & 7 \\
\hline \begin{tabular}{|l|} 
Selçuk Üni. \\
\end{tabular} & 11 & $48 \%$ & 3 & $13 \%$ & 2 & $9 \%$ & 1 & $4 \%$ & & & & & 2 & $9 \%$ & & & & & 4 & $17 \%$ & & & 23 \\
\hline \begin{tabular}{|l|} 
Yaşar Üni. \\
\end{tabular} & & & 1 & $50 \%$ & & & & & & & & & & & & & 1 & $50 \%$ & & & & & 2 \\
\hline Yeditepe Üni. & 1 & $50 \%$ & 1 & $50 \%$ & & & & & & & & & & & & & & & & & & & 2 \\
\hline Yeni Yüzyıl Üni. & & & & & & & & & & & & & & & & & & & 1 & $100 \%$ & & & 1 \\
\hline Toplam & 182 & $44 \%$ & 31 & $8 \%$ & 53 & $13 \%$ & 22 & $5 \%$ & 11 & $3 \%$ & 12 & $3 \%$ & 10 & $2 \%$ & 8 & $2 \%$ & 43 & $11 \%$ & 34 & $8 \%$ & 3 & $1 \%$ & 409 \\
\hline
\end{tabular}

Üniversiteler özelinde 15 ve üzerinde tezin yapıldığı okullarda ideoloji çözümlemesi ağırlıklı olarak güncel siyaset üzerinden ele alınmıştır. Güncel siyaset en fazla çözümleme Ankara ve Gazi'de tartışılmıştır. Toplumsal cinsiyet konusunda Marmara, kimlik ve ekonomi konularında Ankara, çevre ve kültür konularında Ege, sağlık konusunda Anadolu ve Gazi, spor konusunda Anadolu ve İstanbul, şiddet konusunda Gazi öne çıan üniversiteler olmuştur.

Konu çeşitliliği noktasından incelediğimizde Marmara'da her konuda en az bir çalışma yapılmıştır. Anadolu ve Ege'de konu çeşitliliğinin yüksek olduğu diğer üniversitelerdir. Son olarak incelenen tezlerde din konusunun gazete haberleri üzerinden ele alınmamış olması dikkat çekicidir. Laiklik, siyasal İslam, türban gibi konular ele alınsa da bunlar siyasi tartışmalar bağlamında değerlendirilmiş ve sorunsallaştırılmıştır. Doğrudan din ve ideoloji tartışması yapılmamıştır.

\footnotetext{
${ }^{22}$ Tablodaki konular belirlenirken önce başlıkların oluşturulması ve altına tezlerin dağıııılması yöntemi seçilmemiştir. Tezler konusal olarak incelenmeye başlanmış ve gidişata göre tezlerde ön plana çıkan konu başlıkları belirlenmiştir. Bu yöntem tezlerin seçilmiş bir başlı altına konulması zorunluluğunu ortadan kaldırmış ve daha sağlıklı bir sınıflandırma yapılmasını sağlamıştır. Buradaki diğer önemli nokta ise "ön plana çıkan konu”nun seçilmesidir. Tezleri inceleme esnasında bir çalışmanın konusal olarak iki ya da üç başlık altında yer alabileceği görülmüştür. Örneğin "Sağlık Haberlerinde Kadın Bedeninin Sunumu" (Aydın, 2016) ya da "Hekime Yönelik Siiddetin Türk Basınına Yansıması" (Ünvanlı, 2015) başlıklı çalışmalar hem sağlık hem de toplumsal cinsiyet ve şiddet konuları kapsamına girmektedir. Bu noktada ön plana çıkan konu seçilmiș ve çalıșmalar sırasıyla toplumsal cinsiyet ile șiddet başlıkları altında değerlendirilmiștir.
} 
Nitel kısımda yapılan başlıklandırmanın da dayandığı Tablo 5’te evrendeki çalışmaların kuramsal tutumlarına göre dağılımları verilmiştir. ${ }^{23}$ Anaakım ve eleştirel olarak ikiye ayırdığımız çalışmalar, ayrıca eleştirel başlığı altında da gerçeklik yaklaşımlarına göre ikiye bölünmüştür. Tezlerin dağılımına baktığımızda, gazete haberlerini konu alan yüksek lisans tezlerinde eleştirel bakış açısı toplamda 225 tez ile ağırlıktayken anaakım yaklaşım ile yapılan tez sayısı ise 151'dir. Eleştirel tezler arasında ise gerçekliğin basın ile çarpıtıldığı yaklaşımını benimsemiş çalışmalar ön plana çıkmaktadır.

\begin{tabular}{|c|c|c|c|c|c|c|c|c|c|}
\hline \multicolumn{10}{|c|}{$\begin{array}{c}\text { Tablo 5: Tezlerin Üniversitele re ve Kuramsal Yaklaşımlanıa } \\
\text { Göre Dağılımlan }\end{array}$} \\
\hline \multirow{3}{*}{$\begin{array}{l}\text { Tezlerin Yapıldı } \breve{~} \\
\text { Üniversiteler }\end{array}$} & \multicolumn{8}{|c|}{ Tezlerin Kurams al Yaklaşımları } & \multirow{3}{*}{ Toplam } \\
\hline & \multirow{2}{*}{\multicolumn{2}{|c|}{\begin{tabular}{|c|} 
Anaakım \\
Yaklaşımlar \\
ın Ăğır \\
Bastığı \\
Tezler
\end{tabular}}} & \multicolumn{4}{|c|}{$\begin{array}{l}\text { Eleştirel Yaklaşımların Ağır } \\
\text { Bastığı Tezler }\end{array}$} & \multirow{2}{*}{\multicolumn{2}{|c|}{$\begin{array}{l}\text { Değerlendir } \\
\text { ilemeyen }\end{array}$}} & \\
\hline & & & \multicolumn{2}{|c|}{$\begin{array}{c}\text { Gerçekliğin } \\
\text { Çarpırıldığını } \\
\text { Savunan Tezler }\end{array}$} & \multicolumn{2}{|c|}{$\begin{array}{c}\text { Gerçekliğin İnşa } \\
\text { Edildiğini } \\
\text { Savunan Tezler }\end{array}$} & & & \\
\hline Akdeniz Üni. & 1 & $14 \%$ & 2 & $29 \%$ & 4 & $57 \%$ & & & 7 \\
\hline Anadolu Üni. & 25 & $61 \%$ & 7 & $17 \%$ & 5 & $12 \%$ & 4 & $10 \%$ & 41 \\
\hline Ankara Üni. & 11 & $18 \%$ & 28 & $45 \%$ & 19 & $31 \%$ & 4 & $6 \%$ & 62 \\
\hline Atatürk Üni. & 4 & $27 \%$ & 2 & $13 \%$ & 5 & $33 \%$ & 4 & $27 \%$ & 15 \\
\hline Baş kent Üni. & 2 & $100 \%$ & & & & & & & 2 \\
\hline Beykent Üni. & 1 & $100 \%$ & & & & & & & 1 \\
\hline Ege Üni. & 10 & $36 \%$ & 10 & $36 \%$ & 6 & $21 \%$ & 2 & $7 \%$ & 28 \\
\hline Erciyes Üni. & 10 & $59 \%$ & 5 & $29 \%$ & 2 & $12 \%$ & & & 17 \\
\hline Firat Üni. & 4 & $80 \%$ & 1 & $20 \%$ & & & & & 5 \\
\hline Galatas aray Üni. & 1 & $14 \%$ & 2 & $29 \%$ & 2 & $29 \%$ & 2 & $29 \%$ & 7 \\
\hline Gazi Üni. & 30 & $45 \%$ & 22 & $33 \%$ & 11 & $17 \%$ & 3 & $5 \%$ & 66 \\
\hline Gaziantep Üni. & & & & & 2 & $100 \%$ & & & 2 \\
\hline Girne Amerikan Üni. & & & & & & & 1 & $100 \%$ & 1 \\
\hline Hacettepe Üni. & & & 1 & $50 \%$ & 1 & $50 \%$ & & & 2 \\
\hline İhs an D. Bilkent Üni. & & & & & 1 & $100 \%$ & & & 1 \\
\hline İstanbul Arel Üni. & 1 & $17 \%$ & 3 & $50 \%$ & 2 & $33 \%$ & & & 6 \\
\hline İs tanbul Aydın Üni. & 1 & $100 \%$ & & & & & & & 1 \\
\hline İs tanbul Bilgi Üni. & 1 & $33 \%$ & 1 & $33 \%$ & 1 & $33 \%$ & & & 3 \\
\hline İs tanbul Kültür Üni. & 1 & $100 \%$ & & & & & & & 1 \\
\hline İs tanbul Ticaret Üni. & 1 & $50 \%$ & 1 & $50 \%$ & & & & & 2 \\
\hline İs tanbul Üni. & 14 & $34 \%$ & 20 & $49 \%$ & 2 & $5 \%$ & 5 & $12 \%$ & 41 \\
\hline Kadir Has Üni. & & & 1 & $50 \%$ & 1 & $50 \%$ & & & 2 \\
\hline Kocaeli Üni. & 9 & $50 \%$ & 2 & $11 \%$ & 5 & $28 \%$ & 2 & $11 \%$ & 18 \\
\hline Marmara Üni. & 15 & $35 \%$ & 17 & $40 \%$ & 5 & $12 \%$ & 6 & $14 \%$ & 43 \\
\hline $\begin{array}{l}\text { Orta Doğu Teknik } \\
\text { Üni. } \\
\end{array}$ & & & 4 & $57 \%$ & 3 & $43 \%$ & & & 7 \\
\hline Selçuk Üni. & 8 & $35 \%$ & 12 & $52 \%$ & 3 & $13 \%$ & & & 23 \\
\hline Yaş ar Üni. & & & & & 2 & $100 \%$ & & & 2 \\
\hline Yeditepe Üni. & 1 & $50 \%$ & 1 & $50 \%$ & & & & & 2 \\
\hline Yeni Yüzyıl Üni. & & & 1 & $100 \%$ & & & & & 1 \\
\hline Toplam & 151 & $37 \%$ & 143 & $35 \%$ & 82 & $20 \%$ & 33 & $8 \%$ & 409 \\
\hline
\end{tabular}

Tablo 5’i üniversiteler özelinde ele aldığımızda Ankara Üniversitesi (47 tez) çatısı altında yapılan çalışmalarda eleştirel araştırmaların sayıca üstün olduğunu söylemek gerekir. Arkasından ise Gazi (33

\footnotetext{
${ }^{23}$ Tezlerin bazılarında anaakım ve eleştirel bakış açıları bir arada kullanılmış, eklektik bir yapı ortaya çıkmıştır. Bu durumda çalışmalar başlıklara dağıtılırken araştırmalarda ağırlık verilen yaklaşım göz önünde bulundurulmuştur. Bunlara ek olarak anaakım ve eleştirel ayrımı yapılırken çalışmalarda kullanılan kavramlar da dikkate alınmıștır. Örneğin medyanın öteki söylemi yarattığı yönünde eleștiri getiren bir çalışmada (Demirkürek, 2003) çözüm olarak liberal ilkeler sunulduğu için bahsi geçen tez anaakım başlığı altına alınmıştır. Kısacası belirleyici olan sadece eleștirmek değildir. Liberal ilkelerin uygulanmadığını eleștiren bir araştırma anaakım sınıfına dâhil edilmiștir.
} 
tez), İstanbul (22 tez) ve Marmara (22 tez) Üniversiteleri gelmektedir. Öne çıkan bu üniversitelerde eleştirel araştırmalar bağlamında gerçekliğin çarpıtıldığını anlayışını benimsemiş çalışmalar daha fazla yapılmıştır. Anaakım yaklaşımların ağır bastığı tezlerin üniversitelere göre dağılımlarına baktığımızda ise Anadolu (25 tez) ve Gazi (30 tez) Üniversitelerinde sayıca fazla çalışma tamamlanmıştır. Sonrasında ise İstanbul (14 tez) ve Marmara (15 tez) Üniversiteleri gelmektedir.

Eleştirel ve anaakım tezler arasındaki fark üzerinden ele aldığımızda Anadolu Üniversitesi’nde (anaakım tez 25, eleştirel tez 12) anaakım, Ankara Üniversitesi'nde (eleştirel tez 47, anaakım tez 11) eleştirel anlayışın yerleşmiş ve ağır basan gelenek olduğunu Tablo 5’e bakarak söylemek mümkündür.

Evreni oluşturan çalışmaları yöntemleri üzerinden incelediğimizde içerik analizinin yüzde 44 oranla 180 tezde en fazla tercih edildiğini Tablo 6'da görebiliriz. Sonrasında ise (eleştirel) söylem çözümlemesi, ${ }^{24}$ yüzde 29 oran ile 120 tezde kullanılmıştır, ${ }^{25}$ Bu iki yöntem 32 tezde (yüzde 8) birlikte kullanılırken diğer yöntemler 35 tezde (yüzde 9) benimsenmiştir. Çalışmanın evrenindeki 42 tez (yüzde 10), özetinin yetersiz olması ve içeriğine erişimin mümkün olmaması nedeniyle değerlendirilememiştir.

İncelenen tezler bağlamında değerlendirmeyi daha iyi yapmak için evreni oluşturan çalışmalar Tablo 6'da üniversiteler ölçeğinde iki ayrılmıştır. 15 ve üzerinde tez yapılmış 10 üniversite (Anadolu, Ankara, Atatürk, Ege, Erciyes, Gazi, İstanbul, Kocaeli, Marmara ve Selçuk Üniversitesi) ayrı değerlendirilmiş, 15 altında tezin tamamlandığı diğer üniversiteler ise ayrı incelenmiştir.

15 ve üzeri tezin tamamlandığı 10 üniversite içerisinden ele aldığımızda, içerik analizini yöntem olarak kullanan en fazla tez Gazi Üniversitesi’nde (34 tez) tamamlanmıştır. Üniversitelerde içerik analizi yapılan tez sayısının toplam tez sayısına oranı açısından değerlendirdiğimizde bu 10 üniversite arasında Anadolu Üniversitesi yüzde $76^{\prime}$ lık oran ile ilk sırada yer almaktadır. Bu da bize içerik analizi yönteminin diğer üniversitelere göre Anadolu Üniversitesi'nde gazete haberleri üzerine yapılan çalışmalarda daha fazla oranda kullanıldığını göstermektedir. Anadolu Üniversitesi haricinde içerik analizi yöntemiyle yapılan çalışmaların, üniversitede yapılan toplam tez sayısı içindeki oranına baktığımızda; Ankara, Marmara ve Selçuk Üniversiteleri dışında kalanlarda ağırlıkla içerik analizinin tercih edildiğini Tablo 6'da görebiliriz. Ankara, Marmara ve Selçuk Üniversitesi'nde gazete haberlerini incelemede en çok kullanılan yöntem sırasıly yüzde 29'luk, 42'lik, 52'lik oranlar ile (eleştirel) söylem çözümlemesi olmuştur. Tez sayısına göre (eleştirel) söylem çözümlemesini en fazla seçen çalışmalar ise Ankara (18 tez) ve Marmara (18 tez) Üniversitelerinde yapılmıştır. Üniversitelerde tamamlanan tez sayısına oranladığımızda, (eleştirel) söylem çözümlemesi 15 ve üzeri tez yapılan üniversiteler arasında en düşük oranla (yüzde 5) Anadolu Üniversitesi’nde kullanırken, içerik analizi yüzde 27'lik ve 30'luk oranlarla en az Ankara ve Marmara'da tercih edilmiştir.

(Eleştirel) Söylem çözümlemesi ve içerik analizi bir arada en fazla 5 tez ile Ankara Üniversitesi'ndeki iletişim anabilim dallarında yapılan çalışmalarda tercih edilmiştir. Orantısal çerçeveden incelediğimizde ise 10 üniversite arasında yüzde 20 ile en fazla Atatürk Üniversitesi’nde yapılan

\footnotetext{
${ }^{24}$ Söylem çözümlemesi ile eleştirel söylem çözümlemesi arasında fark vardır. Türkiye'deki çalışmalarda merkezine ideoloji tartısmasını alan eleştirel söylem çözümlemesi yapılır (Özer, 2011, s. 9). İncelediğimiz tezlerde yöntemin söylem çözümlemesi olarak belirtilmesine rağmen eleştirel söylem çözümlemesi yapıldığı görülmüştür.

${ }^{25}$ Özet ya da metin kısmında herhangi bir yöntemi benimsediğini belirtmeyen ancak çalışmanın içeriğine baktığımızda gazete metinlerindeki söylemler üzerinden çözümleme yapan 17 çalışma da bu başlı altına dâhil edilmiştir.
} 
çalışmalarda iki yöntemin birlikte uygulandığını Tablo 6'da görebiliriz. Son olarak 15 üstünde çalışmanın tamamlandığı üniversiteler özelinde gazete haberlerinin incelenmesinde ağırlıklı olarak seçilen yöntemin içerik analizi olduğunu belirtmemiz gerekir.

\begin{tabular}{|c|c|c|c|c|c|c|c|c|c|c|c|}
\hline \multicolumn{12}{|c|}{ Tablo 6: Tezlerin Üniversitele re ve Yöntemlerine Göre Dağılımlan } \\
\hline \multirow{3}{*}{$\begin{array}{l}\text { Tezlerin Yapıldı̆̆ı } \\
\text { Üniversiteler }\end{array}$} & \multicolumn{10}{|c|}{ Kulanılan Yöntemler } & \multirow{3}{*}{\begin{tabular}{|r} 
Top \\
lam \\
\\
41 \\
\end{tabular}} \\
\hline & \multicolumn{2}{|c|}{$\begin{array}{l}\text { (Eleştirel) } \\
\text { Söylem } \\
\text { Çözülemesi }\end{array}$} & \multicolumn{2}{|c|}{$\begin{array}{l}\text { İçerik } \\
\text { Analizi }\end{array}$} & \multicolumn{2}{|c|}{$\begin{array}{l}\text { (Eleştirel) } \\
\text { Söylem } \\
\text { Çözümleme } \\
\text { si ve İçerik } \\
\text { Analizi }\end{array}$} & \multicolumn{2}{|c|}{$\begin{array}{c}\text { Diğer } \\
\text { Yöntemler }\end{array}$} & \multicolumn{2}{|c|}{$\begin{array}{l}\text { Değerlendir } \\
\text { ilemeyen }\end{array}$} & \\
\hline & 2 & $5 \%$ & 31 & $76 \%$ & 3 & $7 \%$ & 4 & $10 \%$ & 1 & $2 \%$ & \\
\hline Ankara Üni. & 18 & $29 \%$ & 17 & $27 \%$ & 5 & $8 \%$ & 8 & $13 \%$ & 14 & $23 \%$ & 62 \\
\hline Atatürk Üni. & 5 & $33 \%$ & 7 & $47 \%$ & 3 & $20 \%$ & & & & & 15 \\
\hline Ege Üni. & 7 & $25 \%$ & 11 & $39 \%$ & 3 & $11 \%$ & 4 & $14 \%$ & 3 & $11 \%$ & 28 \\
\hline Erciyes Üni. & 4 & $24 \%$ & 11 & $65 \%$ & 1 & $6 \%$ & 1 & $6 \%$ & & & 17 \\
\hline Gazi Üni. & 11 & $17 \%$ & 34 & $52 \%$ & 4 & $6 \%$ & 9 & $14 \%$ & 8 & $12 \%$ & 66 \\
\hline İstanbul Üni. & 11 & $27 \%$ & 20 & $49 \%$ & 3 & $7 \%$ & 1 & $2 \%$ & 6 & $15 \%$ & 41 \\
\hline Kocaeli Üni. & 2 & $11 \%$ & 13 & $72 \%$ & & & & & 3 & $17 \%$ & 18 \\
\hline Marmara Üni. & 18 & $42 \%$ & 13 & $30 \%$ & 4 & $9 \%$ & 3 & $7 \%$ & 5 & $12 \%$ & 43 \\
\hline Selçuk Üni. & 12 & $52 \%$ & 9 & $39 \%$ & 1 & $4 \%$ & 1 & $4 \%$ & & & 23 \\
\hline Akdeniz Üni. & 5 & $71 \%$ & 1 & $14 \%$ & & & 1 & $14 \%$ & & & 7 \\
\hline Baş kent Üni. & & & 1 & $50 \%$ & & & & & 1 & $50 \%$ & 2 \\
\hline Beykent Üni. & & & 1 & $100 \%$ & & & & & & & 1 \\
\hline Firat Üni. & 3 & $60 \%$ & 2 & $40 \%$ & & & & & & & 5 \\
\hline Galatas aray Üni. & 4 & $57 \%$ & 1 & $14 \%$ & 1 & $14 \%$ & & & 1 & $14 \%$ & 7 \\
\hline Gaziantep Üni. & 2 & $100 \%$ & & & & & & & & & 2 \\
\hline Girne Amerikan Üni. & 1 & $100 \%$ & & & & & & & & & 1 \\
\hline Hacettepe Üni. & 2 & $100 \%$ & & & & & & & & & 2 \\
\hline İhs an D. Bilkent Üni. & 1 & $100 \%$ & & & & & & & & & 1 \\
\hline İstanbul Arel Üni. & 4 & $67 \%$ & & & 1 & $17 \%$ & 1 & $17 \%$ & & & 6 \\
\hline İs tanbul Aydın Üni. & & & 1 & $100 \%$ & & & & & & & 1 \\
\hline İs tanbul Bilgi Üni. & 1 & $33 \%$ & 1 & $33 \%$ & & & 1 & $33 \%$ & & & 3 \\
\hline İs tanbul Kültür Üni. & 1 & $100 \%$ & & & & & & & & & 1 \\
\hline İstanbul Ticaret Üni. & & & & & 1 & $50 \%$ & 1 & $50 \%$ & & & 2 \\
\hline Kadir Has Üni. & 1 & $50 \%$ & & & 1 & $50 \%$ & & & & & 2 \\
\hline Orta Doğu Teknik Üni. & 2 & $29 \%$ & 4 & $57 \%$ & 1 & $14 \%$ & & & & & 7 \\
\hline Yaşar Üni. & 1 & $50 \%$ & 1 & $50 \%$ & & & & & & & 2 \\
\hline Yeditepe Üni. & 1 & $50 \%$ & 1 & $50 \%$ & & & & & & & 2 \\
\hline Yeni Yüzyıl Üni. & 1 & $100 \%$ & & & & & & & & & 1 \\
\hline Toplam & 120 & $29 \%$ & 180 & $44 \%$ & 32 & $8 \%$ & 35 & $9 \%$ & 42 & $10 \%$ & 409 \\
\hline
\end{tabular}

Tez sayılarının azlığı, 15’in altında tezin tamamlandığı üniversitelerde orantısal bir değerlendirme yapmaya imkân tanımamaktadır. Ancak yöntem dağılımlarını tez sayıları üzerinden incelemek mümkündür. (Eleştirel) Söylem çözümlemesinin en çok 5 tez ile Akdeniz Üniversitesi'nde, içerik çözümlemesinin ise en fazla 4 çalışma ile ODTÜ’de kullanıldığını Tablo 6'da görmek mümkündür. Ayrıca yukarıda belirttiğimiz gibi 15 ve üstünde tezin tamamlandığı üniversitelerde ağırlıklı kullanılan yöntem içerik analizi olurken, 15’in altında çalışmanın yapıldığı üniversitelerde çoğunlukla (eleştirel) söylem çözümlemesi tercih edilmiştir. Bunun nedenini 15’in altında tezin yapıldığı üniversitelerin yeni lisansüstü eğitime başlaması ve son dönemde daha çok (eleştirel) söylem çözümlemesinin kullanılmasıyla açıklayabiliriz. Yöntemlerin hangi dönemde ağırlıklı olarak kullanıldığı ise ileride daha ayrıntılı bir biçimde ele alınmıştır. 
Tablo 6'da diğer yöntemler başlığı altında nelerin olduğuna da değirsek, öncelikle alımlama çalışmasının yok denecek kadar az olduğunu belirtmek gerekir. Diğer başlı̆̆ı altına alınan tezlerde yöntem olarak nitel yöntem, kaynak tarama, çerçeveleme, semiyolojik analiz, serbest metin analizi, betimleyici çözümleme, durum tespiti yöntemi, ileti analizi, tipografi analizi gibi yöntemlerin benimsendiği belirtilmiştir.

Bibliyometrik çözümleme ile incelediğimiz gazete haberlerini konu alan 409 tezde, hipotezin kurulup kurulmadığına baktığımızda Tablo 7’ye göre yüzde 53'lük oran ile 217 tezde hipotez sınanmamıştır. 86 tezde (yüzde 21) ise hipotez sınaması yapılırken erişime açık olmaması ya da indirilen dosyaların açılamaması nedeniyle 106 tez (yüzde 26) değerlendirilememiştir.

\begin{tabular}{|c|c|c|c|c|c|c|c|}
\hline \multicolumn{8}{|c|}{$\begin{array}{c}\text { Tablo 7: Tezlerin Üniversitelere ve Hipotez } \\
\text { Durumlarına Göre Dağılımlan }\end{array}$} \\
\hline \multirow{3}{*}{$\begin{array}{l}\begin{array}{c}\text { Tezlerin Yapıldığ } \\
\text { Üniversite }\end{array} \\
\text { Akdeniz Üni. }\end{array}$} & \multicolumn{6}{|c|}{ Hipotez Durumu } & \multirow{3}{*}{\begin{tabular}{|r|} 
Top \\
lam \\
7
\end{tabular}} \\
\hline & \multicolumn{2}{|c|}{ Hipotez Sınanmış } & \multicolumn{2}{|c|}{ Hipotez Sınanmamış } & \multicolumn{2}{|c|}{$\begin{array}{l}\text { Değerlendiri } \\
\text { lemeyen }\end{array}$} & \\
\hline & 2 & $29 \%$ & 2 & $29 \%$ & 3 & $43 \%$ & \\
\hline Anadolu Üni. & 7 & $17 \%$ & 22 & $54 \%$ & 12 & $29 \%$ & 41 \\
\hline Ankara Üni. & 16 & $26 \%$ & 20 & $32 \%$ & 26 & $42 \%$ & 62 \\
\hline Atatürk Üni. & 2 & $13 \%$ & 10 & $67 \%$ & 3 & $20 \%$ & 15 \\
\hline Baş kent Üni. & & & 2 & $100 \%$ & & & 2 \\
\hline Beykent Üni. & & & 1 & $100 \%$ & & & 1 \\
\hline Ege Üni. & 2 & $7 \%$ & 11 & $39 \%$ & 15 & $54 \%$ & 28 \\
\hline Erciyes Üni. & 6 & $35 \%$ & 10 & $59 \%$ & 1 & $6 \%$ & 17 \\
\hline Firat Üni. & 2 & $40 \%$ & 1 & $20 \%$ & 2 & $40 \%$ & 5 \\
\hline Galatas aray Üni. & 1 & $14 \%$ & 6 & $86 \%$ & & & 7 \\
\hline Gazi Üni. & 21 & $32 \%$ & 28 & $42 \%$ & 17 & $26 \%$ & 66 \\
\hline Gaziantep Üni. & & & 1 & $50 \%$ & 1 & $50 \%$ & 2 \\
\hline Girne Amerikan Üni. & & & 1 & $100 \%$ & & & 1 \\
\hline Hacettepe Üni. & & & 2 & $100 \%$ & & & 2 \\
\hline İhs an D. Bilkent Üni. & & & 1 & $100 \%$ & & & 1 \\
\hline İs tanbul Arel Üni. & 2 & $33 \%$ & 3 & $50 \%$ & 1 & $17 \%$ & 6 \\
\hline İs tanbul Aydın Üni. & 1 & $100 \%$ & & & & & 1 \\
\hline İs tanbul Bilgi Üni. & & & 3 & $100 \%$ & & & 3 \\
\hline İs tanbul Kültür Üni. & & & 1 & $100 \%$ & & & 1 \\
\hline İstanbul Ticaret Üni. & & & 1 & $50 \%$ & 1 & $50 \%$ & 2 \\
\hline İstanbul Üni. & 4 & $10 \%$ & 31 & $76 \%$ & 6 & $15 \%$ & 41 \\
\hline Kadir Has Üni. & & & 2 & $100 \%$ & & & 2 \\
\hline Kocaeli Üni. & 7 & $39 \%$ & 5 & $28 \%$ & 6 & $33 \%$ & 18 \\
\hline Marmara Üni. & 3 & $7 \%$ & 31 & $72 \%$ & 9 & $21 \%$ & 43 \\
\hline Orta Doğu Teknik Üni. & & & 6 & $86 \%$ & 1 & $14 \%$ & 7 \\
\hline Selçuk Üni. & 8 & $35 \%$ & 13 & $57 \%$ & 2 & $9 \%$ & 23 \\
\hline Yaș ar Üni. & & & 2 & $100 \%$ & & & 2 \\
\hline Yeditepe Üni. & 1 & $50 \%$ & 1 & $50 \%$ & & & 2 \\
\hline Yeni Yüzyıl Üni. & 1 & $100 \%$ & & & & & 1 \\
\hline Toplam & 86 & $21 \%$ & 217 & $53 \%$ & 106 & $26 \%$ & 409 \\
\hline
\end{tabular}

En fazla Ankara ile Gazi Üniversitelerinde 16 ve 21 tezde hipotez sınaması yapılmıştır. Ancak bu üniversitelerde de hipotezin sınanmadığı tez sayısının daha fazla olduğunu Tablo 7'de görebiliriz. Diğer taraftan hipotez sınanmayan en fazla tezin yapıldığ üniversiteler, 31'er çalışma ile İstanbul ve Marmara'dır. Ayrıca bu üniversitelerde tamamlanan toplam tez sayısına, hipotez sınanan çalışmaları oranladığımızda yüzde 10 ve 7 gibi oldukça düşük oranların çıktığını söylememiz gerekir. 
İçerik çözümlemesi yöntemi ile hipotez kurulma ilişkisini inceleyecek olursak Tablo 6 ve 7 karşılaştırmasını yapmamız gerekir. İlk olarak en fazla içerik çözümlemesi yönteminin kullanıldığı ve hipotezin sınandığı üniversitenin Gazi Üniversitesi olduğunu söylemeliyiz. Ancak Anadolu ve İstanbul Üniversitelerinde 31 ve 20 tezde içerik çözümlemesinin kullanılmasına rağmen hipotezin sınandığı çalışma sayısının düşük olması, içerik çözümlemesi yöntemi ile hipotez sınaması yapılması arasında doğru orantı olduğu çıkarımını yapmamızı engellemektedir. Kısacası, ampirik çizgide olmaları nedeniyle her ne kadar ilk bakışta içerik çözümlemesi yönteminin kullanıldığı çalışmalarda hipotez sınama oranının yüksek olduğu gibi anlayış hâkim olsa da Tablo 6 ve 7'deki verilerin karşılaştırılması bu varsayımı yanlışlamaktadır.

Üniversitelerin iletişim anabilim dalları altında yapılan tezlerde incelenen gazeteleri yerel, ulusal, yabancı ile ulusal ve yabancı basın başlıklarında sınıflandırmak, ideolojinin üniversiteler özelinde ağırlıklı olarak hangi kapsamda ele alındığı hakkında bilgi sahibi olmamızı sağlamıştır. Tablo 8'e bakarsak evreni oluşturan tezlerin yüzde $83^{\prime}$ ünde (340 tez), ulusal çapta basılan gazetelerin ele alındığını söyleyebiliriz. Geriye kalanların yüzde 5 'inde ${ }^{26}$ (19 tez) yerel gazeteleri, yüzde 5 'inde (19 tez) yabancı gazeteleri, yine yüzde 5'inde (19 tez) ise ulusal ve yabancı basını bir arada konu alan tezler yapılmıştır. Özet kısımlarının yetersiz kalması ya da erişime açık olmamaları nedeniyle yüzde 3 (12 tez) oranında çalışma değerlendirilememiştir.

Üniversitelerde tamamlanan toplam tez sayısına göre yerel basını ele alan çalışmaların oranının en yüksek olduğu üniversiteler, toplam tez sayısı düşük olan Gaziantep (yüzde 100) ile Selçuk'tur (yüzde 22). Sayısal olarak ele aldığımızda da 5 çalışma ile yerel basın en fazla Selçuk Üniversitesi'nde incelenmiştir. 15 ve üzerinde tezin tamamlandığı üniversiteler arasında Ankara ve Kocaeli'de yerel basın hiçbir tezde tartışma konusu edilmemiştir.

Türkiye'de yerel basının belirli yerlerde geliştiğini ve genel anlamda da ayakta durması için yerel siyasi oluşumların ya da sivil toplum kuruluşlarının desteğine ihtiyacının olduğunu göz önüne alırsak içeriklerinin ideolojik olarak sorgulanmaya ihtiyacı olduğunu söyleyebiliriz. Ancak bununla birlikte Tablo 8'e göre yerel basın yüksek lisans tezlerinde oldukça düşük seviyede konu edilmesi, bu alanda araştırmaların yapılması ihtiyacını bize göstermektedir.

Tablo 8'de ulusal basının en fazla konu edildiği çalışma Ankara (56) ve Gazi'de (55) yapılmıştır. Ulusal basının tezlerde hiç konu edilmediği Gaziantep ve Yaşar Üniversitesi'nin bu durumu ise yapılan tez sayılarının düşük olması ile açıklanabilir.

Son olarak yabancı basının en fazla 4 çalışma ile İstanbul'da ele alındığını Tablo 8'de görebiliriz. Gazi Üniversitesi'nde yapılan 4 çalışmada ise ulusal ve yabancı basını aynı anda incelenmiştir. Yabancı basını kapsamına alan çalışmaların bu kadar az yapılması, Türkiye'de yaşanan yabancı dil problemiyle açıklanabilir gibi görünse de yabancı dilde eğitim yapan Galatasaray ve Bilgi Üniversiteleri ile ODTÜ'de de yabancı basının inceleme konusu yapılması düşük seviyede kalmıştır.

Genel olarak Tablo 8'e baktığımızda ulusal basının tartışıldığı çalışmalar ağır basmakla birlikte Anadolu, Gazi, İstanbul, Marmara Üniversitelerinde her kapsamdaki gazeteler inceleme konusu edilmiştir.

\footnotetext{
${ }^{26}$ Ege Üniversitesi’nde ulusal ve yerel basını aynı anda ele alan iki çalışma yerel başlığı altına alınmıştır.
} 


\begin{tabular}{|c|c|c|c|c|c|c|c|c|c|c|c|}
\hline \multicolumn{12}{|c|}{$\begin{array}{c}\text { Tablo 8: Tezlerin Üniversitelere ve Tezlerde İncelenen Gazetelerin } \\
\text { Kapsamına Göre Dağılımları }\end{array}$} \\
\hline \multirow{3}{*}{$\begin{array}{l}\text { Tezlerin Yapıldı ğı } \\
\text { Üniversiteler }\end{array}$} & \multicolumn{10}{|c|}{ Gazete Kaps amları } & \multirow{3}{*}{\begin{tabular}{|r|}
$\begin{array}{c}\text { Top } \\
\text { am }\end{array}$ \\
7
\end{tabular}} \\
\hline & \multicolumn{2}{|c|}{ Yerel Basin } & \multicolumn{2}{|c|}{$\begin{array}{l}\text { Ulus al } \\
\text { Basin }\end{array}$} & \multicolumn{2}{|c|}{$\begin{array}{c}\text { Yabancı } \\
\text { Basın }\end{array}$} & \multicolumn{2}{|c|}{$\begin{array}{c}\text { Ulusal ve } \\
\text { Yabancı } \\
\text { Basın } \\
\end{array}$} & \multicolumn{2}{|c|}{$\begin{array}{c}\text { Değerlendi } \\
\text { rilemeyen }\end{array}$} & \\
\hline & & & 7 & $100 \%$ & & & & & & & \\
\hline Anadolu Üni. & 1 & $2 \%$ & 36 & $88 \%$ & 2 & $5 \%$ & 1 & $2 \%$ & 1 & $2 \%$ & 41 \\
\hline Ankara Üni. & & & 56 & $90 \%$ & 3 & $5 \%$ & 1 & $2 \%$ & 2 & $3 \%$ & 62 \\
\hline Atatürk Üni. & 2 & $13 \%$ & 10 & $67 \%$ & & & 2 & $13 \%$ & 1 & $7 \%$ & 15 \\
\hline Baş kent Üni. & & & 2 & $100 \%$ & & & & & & & 2 \\
\hline Beykent Üni. & & & 1 & $100 \%$ & & & & & & & 1 \\
\hline Ege Üni. & 2 & $7 \%$ & 23 & $82 \%$ & 1 & $4 \%$ & 1 & $4 \%$ & 1 & $4 \%$ & 28 \\
\hline Erciyes Üni. & 1 & $6 \%$ & 15 & $88 \%$ & & & 1 & $6 \%$ & & & 17 \\
\hline Furat Üni. & & & 5 & $100 \%$ & & & & & & & 5 \\
\hline Galatas aray Üni. & & & 6 & $86 \%$ & 1 & $14 \%$ & & & & & 7 \\
\hline Gazi Üni. & 2 & $3 \%$ & 55 & $83 \%$ & 4 & $6 \%$ & 4 & $6 \%$ & 1 & $2 \%$ & 66 \\
\hline Gaziantep Üni. & 2 & $100 \%$ & & & & & & & & & 2 \\
\hline Girne Amerikan Üni. & & & 1 & $100 \%$ & & & & & & & 1 \\
\hline Hacettepe Üni. & & & 2 & $100 \%$ & & & & & & & 2 \\
\hline İhs an D. Bilkent Üni. & & & 1 & $100 \%$ & & & & & & & 1 \\
\hline İstanbul Arel Üni. & & & 6 & $100 \%$ & & & & & & & 6 \\
\hline İstanbul Aydın Üni. & & & 1 & $100 \%$ & & & & & & & 1 \\
\hline İstanbul Bilgi Üni. & & & 3 & $100 \%$ & & & & & & & 3 \\
\hline İstanbul Kültür Üni. & & & 1 & $100 \%$ & & & & & & & 1 \\
\hline İstanbul Ticaret Üni. & & & 2 & $100 \%$ & & & & & & & 2 \\
\hline İstanbul Üni. & 1 & $2 \%$ & 31 & $76 \%$ & 4 & $10 \%$ & 3 & $7 \%$ & 2 & $5 \%$ & 41 \\
\hline Kadir Has Üni. & & & 2 & $100 \%$ & & & & & & & 2 \\
\hline Kocaeli Üni. & & & 12 & $67 \%$ & 1 & $6 \%$ & 2 & $11 \%$ & 3 & $17 \%$ & 18 \\
\hline Marmara Üni. & 2 & $5 \%$ & 36 & $84 \%$ & 1 & $2 \%$ & 3 & $7 \%$ & 1 & $2 \%$ & 43 \\
\hline Orta Doğu Teknik Üni. & 1 & $14 \%$ & 6 & $86 \%$ & & & & & & & 7 \\
\hline Selçuk Üni. & 5 & $22 \%$ & 17 & $74 \%$ & & & 1 & $4 \%$ & & & 23 \\
\hline Yaş ar Üni. & & & & & 2 & $100 \%$ & & & & & 2 \\
\hline Yeditepe Üni. & & & 2 & $100 \%$ & & & & & & & 2 \\
\hline Yeni Yüzyıl Üni. & & & 1 & $100 \%$ & & & & & & & 1 \\
\hline Toplam & 19 & $5 \%$ & 340 & $83 \%$ & 19 & $5 \%$ & 19 & $5 \%$ & 12 & $3 \%$ & 409 \\
\hline
\end{tabular}

\section{Tezlerin Yıllara Göre Dağılımları}

Üniversitelere göre dağılımlarını ele aldığımız kısımda olduğu gibi bu başlık altında da tezler anabilim dalı, yöntem, konu, kuramsal yaklaşım, kapsam ve hipotez durumlarına göre değerlendirilmiştir.

Öncelikle anabilim dallarına göre evrendeki çalışmaların dağılımını ele alırsak, birinci dönemde sadece gazetecilik anabilim dalında tezin tamamlandığını Tablo 9'da görebiliriz. Ancak bu dönemdeki çalışmaların yüzde 79'unun değerlendirilemediğine dikkat edersek dönem hakkında genel bir çıkarım yapmamızın mümkün olmadığını söylemeliyiz. Değerlendirememe oranının bu kadar yüksek olması ise eski tarihli çalışmaların künyelerinin eksik girilmesinden kaynaklanmaktadır. İkinci dönemde diğer anabilim dallar ${ }^{27}$ dışında her anabilim dalında çalışma yapılmıştır (Tablo 9). En fazla çalışma ise gazetecilik anabilim dallarında (33 tez) tamamlanmıştır. Tablo 9'daki üçüncü döneme bakarsak diğer dönemlerde olduğu gibi bu dönemde de en fazla çalışma 168 tez ile gazetecilik anabilim dalları altında teslim edilmiştir.

\footnotetext{
${ }^{27}$ Diğer anabilim dallarına önceki başlıkta değinilmiștir.
} 


\begin{tabular}{|c|c|c|c|c|}
\hline \multicolumn{5}{|c|}{$\begin{array}{c}\text { Tablo 9: Tezle rin Yıllara ve Anabilim Dallarına } \\
\text { Göre Dağılımlan }\end{array}$} \\
\hline \multirow{2}{*}{ Anabilim Dalları } & \multicolumn{4}{|c|}{ Tezlerin Yapıldd̆̆ı Dönem } \\
\hline & $\begin{array}{l}\text { 1. Dönem } \\
\text { 1985-1997 }\end{array}$ & $\begin{array}{l}\text { 2. Dönem } \\
\text { 1998-2005 }\end{array}$ & $\begin{array}{c}\text { 3. Dönem } \\
\text { 2006-2016 }\end{array}$ & Toplam \\
\hline \multirow{2}{*}{ Basın Yayın } & & 7 & 18 & 25 \\
\hline & & $8 \%$ & $6 \%$ & $6 \%$ \\
\hline \multirow{2}{*}{ Gazetecilik } & 4 & 33 & 168 & 205 \\
\hline & $21 \%$ & $39 \%$ & $55 \%$ & $50 \%$ \\
\hline \multirow{2}{*}{$\begin{array}{l}\text { Halkla İliş kiler ve } \\
\text { Tanıtım }\end{array}$} & & 7 & 37 & 44 \\
\hline & & $8 \%$ & $12 \%$ & $11 \%$ \\
\hline \multirow{2}{*}{ Illetişim Bilimleri } & & 3 & 25 & 28 \\
\hline & & $4 \%$ & $8 \%$ & $7 \%$ \\
\hline \multirow{2}{*}{$\begin{array}{l}\text { Radyo Televizyon (ve } \\
\text { Sinema) }\end{array}$} & & 7 & 29 & 36 \\
\hline & & $8 \%$ & $10 \%$ & $9 \%$ \\
\hline \multirow{2}{*}{$\begin{array}{l}\text { Diğer Anabilim } \\
\text { Dalları }\end{array}$} & & & 21 & 21 \\
\hline & & & $7 \%$ & $5 \%$ \\
\hline \multirow{2}{*}{ Değerlendirilemeyen } & 15 & 28 & 7 & 50 \\
\hline & $79 \%$ & $33 \%$ & $2 \%$ & $12 \%$ \\
\hline Toplam & 19 & 85 & 305 & 409 \\
\hline
\end{tabular}

Anabilim dallarında yapılan tezlerin sayıca ve dönem içerisindeki toplam tez sayısına oranlarındaki değişimini ele aldığımızda iletişim bilimleri ile diğer anabilim dalları başlığı altında yapılan çalışmalara ait veriler önemlidir. ${ }^{28}$ İletişim bilimlerinde ikinci dönemden üçüncü döneme tez sayısı 3’ten 25 'e çıkmış ve 8,3 kat artmıştır. Diğer anabilim dallarında ise ikinci dönemde hiç çalışma yapılmamışken üçüncü dönemde 21 tez tamamlanmıştır. Buradaki artışın fazla olmasının nedeni diğer anabilim dalları altına aldığımız bölümlerin sayıca ( 9 bilim ya da anabilim dalı) çok ve son dönemde açılmış olmalarıdır. Anabilim dalında yapılan çalışmaların orantısal artışı yine en fazla iletişim bilimlerinde (yüzde 4'ten 8'e) olmuştur. Basın yayın anabilim dalı altında yapılan çalışmalarda sayıca bir artış olmasına rağmen orantısal (yüzde 8'den 6’ya) bir düşüş yaşanmıştır.

Gazete haberleri üzerine yapılan yüksek lisans tezlerinde ön plana çıkan konunun yıllara göre dağılımına baktığımızda, birinci dönemde toplumsal cinsiyet, kimlik, sağlık ve kültür üzerinden ideolojinin çözümlenmediğini Tablo 10 görebiliriz. İkinci dönemde sağlık ve spor konusunda tez yapılmamışken üçüncü dönemde her konuda çalışma yapılmıştır.

Konular özelinde üç dönemde de ağırlıklı olarak güncel siyaset çalışılmıştır. Tezlerdeki çalışma konularının dönemlere göre değişimlerini ele aldığımızda, spor dışındaki her alanda yapılan çalışma

\footnotetext{
${ }^{28}$ İnceleyeceğimiz tablolardaki oranlamalar dönemde tamamlanan toplam tez sayısına göre yapılmıştır. Örneğin birinci dönemde gazetecilik anabilim dalında yapılan beș tezin gazetecilik başlığı altında yapılmış tüm tezlere oranı değil, birinci dönemde yapılan toplam tez sayısına oranı verilmiştir. Çalışmadaki amacımızın dönemlere göre tezlerin değişimini ele almak olduğu için böyle bir oranlama tercih edilmiştir. Tabloların toplam sütununda bir başlıktaki toplam tez sayısına ve bunların evrene göre oranlarına yer verilmiştir. Bu değerler tezlerin üniversitelere göre dağılımlarını incelediğimiz tablolardaki yatay toplam sütunu ile aynı olduğu için burada tekrar değerlendirilmemiştir. Toplam satırında ise her dönemde yapılan tez sayısı gösterilmiștir.
} 
sayısında artış olmuştur. En fazla artış ise 100 tez ile (38'den 138 'e) güncel siyaset alanında, ikinci dönemden üçüncü döneme geçişte yaşanmıştır.

\begin{tabular}{|c|c|c|c|c|}
\hline \multicolumn{5}{|c|}{ Tablo 10: Tezlerin Yıllara ve Konularına Göre Dağılımları } \\
\hline \multirow[b]{2}{*}{ Konular } & \multicolumn{4}{|c|}{ Tezlerin Yapıldı̆̆ı Dönemler } \\
\hline & $\begin{array}{c}\text { 1. Dönem } \\
\text { 1985-1997 }\end{array}$ & $\begin{array}{l}\text { 2. Dönem } \\
\text { 1998-2005 }\end{array}$ & $\begin{array}{c}\text { 3. Dönem } \\
\text { 2006-2016 }\end{array}$ & Toplam \\
\hline \multirow{2}{*}{ Güncel Siyas et } & 6 & 38 & 138 & 182 \\
\hline & $32 \%$ & $45 \%$ & $45 \%$ & $44 \%$ \\
\hline \multirow{2}{*}{ Toplumsal Cinsiyet } & & 5 & 26 & 31 \\
\hline & & $6 \%$ & $9 \%$ & $8 \%$ \\
\hline \multirow{2}{*}{ Kimlik } & & 8 & 45 & 53 \\
\hline & & $9 \%$ & $15 \%$ & $13 \%$ \\
\hline \multirow{2}{*}{ Ekonomi } & 2 & 6 & 14 & 22 \\
\hline & $11 \%$ & $7 \%$ & $5 \%$ & $5 \%$ \\
\hline \multirow{2}{*}{ Çevre } & 2 & 4 & 5 & 11 \\
\hline & $11 \%$ & $5 \%$ & $2 \%$ & $3 \%$ \\
\hline \multirow{2}{*}{ Sağlık } & & & 12 & 12 \\
\hline & & & $4 \%$ & $3 \%$ \\
\hline \multirow{2}{*}{ Kültür } & & 3 & 7 & 10 \\
\hline & & $4 \%$ & $2 \%$ & $2 \%$ \\
\hline \multirow{2}{*}{ Spor } & 2 & & 6 & 8 \\
\hline & $11 \%$ & & $2 \%$ & $2 \%$ \\
\hline \multirow{2}{*}{ Şiddet } & 1 & 10 & 32 & 43 \\
\hline & $5 \%$ & $12 \%$ & $10 \%$ & $11 \%$ \\
\hline \multirow{2}{*}{ Diğer } & 4 & 10 & 20 & 34 \\
\hline & $21 \%$ & $12 \%$ & $7 \%$ & $8 \%$ \\
\hline \multirow{2}{*}{ Değerlendirilemeyen } & 2 & 1 & & 3 \\
\hline & $11 \%$ & $1 \%$ & & $1 \%$ \\
\hline Toplam & 19 & 85 & 305 & 409 \\
\hline
\end{tabular}

Dönemlerde yapılan toplam tez sayısına bir konuda yapılan tez sayısını oranladığımızda, birinci dönemden ikinci döneme geçişte ekonomi, çevre ve spor alanlarında düşüş olurken diğerlerinde artış olmuştur. İkinci dönemden üçüncü döneme geçişte ise sadece toplumsal cinsiyet, kimlik, sağlık ve spor konularında orantısal artı̧̧ görülmüş̧ür. Çevre konusunda üç dönemde de orantısal bir azalma olduğu Tablo 10'da dikkat çekmektedir. Orantısal anlamda en fazla artış ise kimlik konusunda gerçekleşmiştir. Birinci dönemde kimlik konusu hiçbir tezde tartışılmazken ikinci dönemde yüzde 9 , üçüncü dönemde de yüzde 15 gibi bir oranla ele alınmıştır (Tablo 10).

Evrendeki çalışmaların kuramsal yaklaşımlarının yıllara göre nasıl değişim gösterdiğini Tablo 11 üzerinden incelersek her dönemde her kuramsal yaklaşım altında yapılan tez sayısında artış olmuştur. Anaakım tezler ile eleştirel tezleri karşılaştırdığımızda eleştirel araştırmalardaki artış daha fazladır. Eleştirel çalışmalar özelinde gerçekliğin inşa edildiğini savunan tezlerde yaşanan artış gerçekliğin çarpıtıldığını benimseyen çalışmalara göre daha fazladır. Birinci dönemde 1, ikinci dönemde 12, üçüncü dönemde 69 tezde gerçekliğin inşası vurgulanmıştır. 


\begin{tabular}{|c|c|c|c|c|c|c|}
\hline \multicolumn{7}{|c|}{$\begin{array}{c}\text { Tablo 11: Tezlerin Yıllara ve Kuramsal Yaklaşımlarına } \\
\text { Göre Dağılımları }\end{array}$} \\
\hline \multirow{2}{*}{\multicolumn{2}{|c|}{ Kuramsal Yaklaşımlar }} & \multicolumn{5}{|c|}{ Tezlerin Yapıldığı Dönemler } \\
\hline & & $\begin{array}{c}\text { 1. Dönem } \\
\text { 1985-1997 } \\
\end{array}$ & \begin{tabular}{|c|} 
2. Dönem \\
$1998-2005$ \\
\end{tabular} & \begin{tabular}{|c|} 
3. Dönem \\
$2006-2016$ \\
\end{tabular} & Toplam & \begin{tabular}{|c|} 
Genel \\
Toplam \\
\end{tabular} \\
\hline \multirow{2}{*}{\multicolumn{2}{|c|}{$\begin{array}{l}\text { Anaakım Yaklaşımların Ăğır } \\
\text { Bastığı Tezler }\end{array}$}} & 11 & 36 & 104 & 151 & 151 \\
\hline & & $58 \%$ & $42 \%$ & $34 \%$ & $37 \%$ & $37 \%$ \\
\hline \multirow{4}{*}{$\begin{array}{c}\text { Eleştirel } \\
\text { Yaklaşımların } \\
\text { Ăğır Bastı̆̆ } \\
\text { Tezler }\end{array}$} & \multirow{2}{*}{$\begin{array}{c}\text { Gerçekliğin } \\
\text { Çarpırıldığını } \\
\text { Savunan Tezler }\end{array}$} & 2 & 31 & 110 & 143 & \multirow{2}{*}{225} \\
\hline & & $11 \%$ & $36 \%$ & $36 \%$ & $35 \%$ & \\
\hline & \multirow{2}{*}{$\begin{array}{l}\text { Gerçekliğin İnşa } \\
\text { Edildiğini } \\
\text { Savunan Tezler }\end{array}$} & 1 & 12 & 69 & 82 & \multirow{2}{*}{$55 \%$} \\
\hline & & $5 \%$ & $14 \%$ & $23 \%$ & $20 \%$ & \\
\hline \multirow{2}{*}{\multicolumn{2}{|c|}{ Değerlendirilemeyen }} & 5 & 6 & 22 & 33 & 33 \\
\hline & & $26 \%$ & $7 \%$ & $7 \%$ & $8 \%$ & $8 \%$ \\
\hline \multicolumn{2}{|c|}{ Toplam } & 19 & 85 & 305 & 409 & 409 \\
\hline
\end{tabular}

Tezlerin kuramsal yaklaşımlarına göre dağılımlarını bir dönemde yapılan toplam tez sayısına oranladığımızda, anaakım çalışmalar bir düşüş içerisindedir. Eleştirel tezler toplamda orantısal olarak bir yükselmede olsa da gerçekliğin çarpıtıldığını savunan araştırmalarda birinci dönemden ikinci döneme geçişte (yüzde 11'den 36'ya) orantısal bir artış görülmekle birlikte, ikinci dönemden üçüncü döneme geçişte orantısal bir değişiklik olmamıştır. Gerçekliğin inşa edildiği anlayışını benimseyen çalışmalarda ise her dönemde orantısal bir yükselme görülmüştür.

Gazete haberlerini konu almış tezlerdeki çözümlemenin dönemlere göre hangi yöntemler ile ele alındığını incelediğimizde, içerik analizinin birinci dönemde 12 tez ile o dönem içerisinde yapılmış tüm çalışmaların yüzde 63'ünde kullanıldığını Tablo 12'de görebiliriz. Bu dönemde (eleştirel) söylem çözümlemesi ise 3 çalışma ve yüzde 16 oranında yöntem olarak benimsenmiş, iki yöntemin bir arada kullanıldığı çalışma ise yapılmamıştır.

İkinci dönemde 38 çalışma ve yüzde 45 oran ile içerik analizi ideoloji çözümlemesinde yöntem olarak tercih edilmiştir. Ancak tez sayısında sayıca artış olsa bile bu yöntemin dönem içerisinde yapılan tez sayısına göre oranının birinci dönemden ikinci döneme geçişte düştüğüne (yüzde 63'den yüzde 45’e) Tablo 12'de dikkat çekmek gerekir. (Eleştirel) Söylem çözümlemesi yöntemi ise bu dönemde 11 çalışmada ve dönem içerisindeki tezlerin yüzde 13'ünde kullanılmıştır. Bu dönemde ayrıca iki yöntemin bir arada ve diğer yöntemlerin ${ }^{29}$ de tezlerde kullanıldığını Tablo 12'de görebiliriz.

Üçüncü dönemde yapılan çalışmalarda yine içerik analizi 130 tez ve yüzde 43 oranla en fazla benimsenen yöntem olmuştur. (Eleştirel) Söylem çözümlemesi ise 106 çalışma ve yüzde 35 oranla ikinci sırada gelmektedir. Burada dikkat çeken nokta ise birinci ve ikinci dönemlere göre hem tez sayısı hem de oranında içerik analizi ve (eleştirel) söylem çözümlemesi arasındaki farkın daha az

\footnotetext{
${ }^{29}$ Tezlerin üniversitelere göre dağılımlarının incelendiği bölümde diğer yöntemler başlığı altında yer alan yöntemlere örnekler verildiği için burada tekrar edilmemiştir.
} 
olduğudur. Bu dönemde ayrıca iki yöntemin bir arada kullanıldığı ve diğer yöntemler ile yapılan çalışmalarda da artış olmuştur (Tablo 12).

\begin{tabular}{|c|c|c|c|c|}
\hline \multicolumn{5}{|c|}{ Tablo 12: Tezlerin Yıllara ve Yöntemlerine Göre Dağılımlan } \\
\hline \multirow{2}{*}{ Kulanılan Yöntemler } & \multicolumn{4}{|c|}{ Tezlerin Yapıldığı Üniversiteler } \\
\hline & $\begin{array}{c}\text { 1. Dönem } \\
\text { 1985-1997 }\end{array}$ & $\begin{array}{c}\text { 2. Dönem } \\
\text { 1998-2005 }\end{array}$ & $\begin{array}{c}\text { 3. Dönem } \\
\text { 2006-2016 }\end{array}$ & Toplam \\
\hline \multirow{2}{*}{$\begin{array}{l}\text { (Eleştirel) Söylem } \\
\text { Çözülemesi }\end{array}$} & 3 & 11 & 106 & 120 \\
\hline & $16 \%$ & $13 \%$ & $35 \%$ & $29 \%$ \\
\hline \multirow{2}{*}{ İçerik Analizi } & 12 & 38 & 130 & 180 \\
\hline & $63 \%$ & $45 \%$ & $43 \%$ & $44 \%$ \\
\hline \multirow{2}{*}{$\begin{array}{l}\text { (Eleştirel) Söylem } \\
\text { Çözümlemesi ve } \\
\text { İçerik Analizi }\end{array}$} & & 3 & 29 & 32 \\
\hline & & $4 \%$ & $10 \%$ & $8 \%$ \\
\hline \multirow{2}{*}{ Diğer Yöntemler } & & 7 & 28 & 35 \\
\hline & & $8 \%$ & $9 \%$ & $9 \%$ \\
\hline \multirow{2}{*}{ Değerlendirilemeyen } & 4 & 26 & 12 & 42 \\
\hline & $21 \%$ & $31 \%$ & $4 \%$ & $10 \%$ \\
\hline Toplam & 19 & 85 & 305 & 409 \\
\hline
\end{tabular}

Tablo 12'den hareketle tüm yöntemler ile yapılan çalışma sayılarında artış olduğunu söyleyebiliriz. Ancak burada dikkat etmemiz gereken nokta, bir dönemde belli bir yöntem ile yapılmış çalışma sayısının, o dönemdeki toplam tez sayısına oranında nasıl değişim yaşandığıdır. Sadece oranlar üzerinden incelediğimizde içerik analizi ile yapılan çalışmaların dönem içerisindeki oranının sırasıyla yüzde 63, 45, 43 olduğunu Tablo 12'de görüyoruz. Buradan içerik analizi yönteminin kullanılmasında orantısal olarak bir düşüşün yaşandığını söyleyebiliriz. Aynı şekilde diğer yöntemler ile yapılan tezlerin sayısında artış olmasına rağmen orantısal artış (yüzde 8'den 9'a çıkmış) çok fazla olmamıştır.

(Eleştirel) Söylem çözümlemesinin dönemlere göre orantısal değişiminde, birinci ve ikinci dönemde yüzde 16'dan 13'e bir düşüş söz konusu iken üçüncü dönemde bu yöntem ile yapılan çalışmaların o dönem içerisindeki tezlere oranı yüzde 35 'e çıkmıştır. Bu da yukarıda değindiğimiz içerik analizi ve (eleştirel) söylem çözümlemesi arasındaki farkın son dönemde kapanmasına neden olmuştur. (Eleştirel) Söylem çözümlemesindeki orantısal artışı iki yöntemin kullanıldığı çalışmalarda da görmek mümkündür. İkinci dönemde iki yöntemin de bir arada kullanıldığı tezlerin oranı yüzde 4 iken üçüncü dönemde yüzde 10'a çıkmıştır. (Eleştirel) Söylem çözümlemesi ile içerik çözümlemesinin bir arada kullanıldığı tez sayılarındaki artışın 10 kat civarında olması oldukça önemlidir. Orantısal olarak ikinci dönemden üçüncü döneme geçişte (eleştirel) söylem çözümlemesinde 2,6 (yüzde 13'den 35’ya), (eleştirel) söylem çözümlemesi ve içerik analizinin bir arada kullanıldığ tezlerde ise 2,5 (yüzde 4'ten yüzde 10'a) artış olmuştur (Tablo 12). Bu noktadan baktığımızda, orantısal artışın sürmesi durumunda, (eleştirel) söylem çözümlemesi yönteminin tek başına ya da içerik analizi ile birlikte gelecekteki çalışmalarda ağılıkla kullanılacağını söyleyebiliriz. 
Tablo 13: Tezlerin Yıllara ve Hipotez Durumlanna Göre Dağılımlan

\begin{tabular}{|c|c|c|c|c|}
\hline \multirow{2}{*}{ Hipotez Durumu } & \multicolumn{4}{|c|}{ Tezlerin Yapıldı̆̆ı Dönemler } \\
\hline & $\begin{array}{c}\text { 1. Dönem } \\
\text { 1985-1997 }\end{array}$ & $\begin{array}{c}\text { 2. Dönem } \\
\text { 1998-2005 }\end{array}$ & $\begin{array}{c}\text { 3. Dönem } \\
\text { 2006-2016 }\end{array}$ & Toplam \\
\hline \multirow{2}{*}{ Hipotez Sınanmış } & 1 & 7 & 78 & 86 \\
\hline & $5 \%$ & $8 \%$ & $26 \%$ & $21 \%$ \\
\hline \multirow{2}{*}{ Hipotez Sınanmamış } & 4 & 19 & 194 & 217 \\
\hline & $21 \%$ & $22 \%$ & $64 \%$ & $53 \%$ \\
\hline \multirow{2}{*}{ Değerlendirilemeyen } & 14 & 59 & 33 & 106 \\
\hline & $74 \%$ & $69 \%$ & $11 \%$ & $26 \%$ \\
\hline Toplam & 19 & 85 & 305 & 409 \\
\hline
\end{tabular}

Gazete haberleri üzerinden ideoloji tartışması yürüten çalışmalarda hipotezin sınanıp sınanmadığını dönemler üzerinden ele alırsak, öncelikle birinci ve ikinci dönemde yüzde 74 ve yüzde 69 oranında çalışmanın erişime açık olmaması nedeniyle değerlendirilemediğine dikkat çekmemiz gerekir (Tablo 13). Bu durum söz konusu dönemlerin incelenmesinde önemli bir sınırlılık olarak karşımıza çıkmaktadır. Ama yine de sayısal ve orantısal olarak iki dönemde de hipotezin sınanmadı̆̆ 1 çalışmaların fazla olduğunu söylemek gerekir. Üçüncü dönemde ise 305 çalışma içerisinde 194 tezde (yüzde 64) hipotez sınaması yapılmadığını Tablo 13’te görebiliriz. Yukarıda belirttiğimiz gibi değerlendirilemeyen çalışma sayısının fazla olmasına rağmen tüm dönemler üzerinden incelediğimizde orantısal olarak en fazla hipotezin sınanmadı̆̆ çalışma üçüncü dönemdedir.

Gazete haberlerini konu alan yüksek lisans tezlerinde dönemlere göre ideolojinin hangi kapsamda ele alındığına baktığımızda, ulusal basının tüm dönemlerde ağırlıklı olarak tartışma konusu yapıldığını Tablo 14'te görebiliriz. Dönemler özelinde ise birinci dönemde sadece yerel ve ulusal basının çalışmalara konu olduğunu söylemek gerekir. Yerel basın bu dönemde 2 (yüzde 11) çalışmada tartışılmıştır. Ulusal basının ele alındığı çalışmalar ise 16 tez ve yüzde 84 'lük oranla karşımıza çıkmaktadır.

Tablo 14'e göre ikinci dönemde tüm başlıklar altında tez yapılmıştır. Ancak yerel basının, yabancı basının, ulusal ve yabancı basının birlikte ele alındığı çalışmalar yüzde 4, 4 ve 1'lik oranlar ile oldukça düşük seviyededir. Dönemde yapılan toplam tez sayısına göre alınan oranları bir önceki dönemle ile karşılaştırdığımızda ikinci dönemde yerel basın çalışmalarında yüzde 11'den 4'e düşüş olmuştur. Ulusal basını ele alan tezlerde ise orantısal olarak bir değişim söz konusu değildir. Bununla birlikte yerel basını konu alan çalışmalar dışında birinci dönemden ikinci döneme geçişte tüm başlıklar altındaki tez sayılarında artış olmuştur. En fazla artış ise 16 tezden 71 teze çıkan ulusal basın konulu tezlerde yaşanmıştır.

Tablo 14 üzerinden üçüncü döneme odaklandığımızda, evrendeki tezlerde ulusal basın ağırlığını (yüzde 84) korumakla birlikte diğer çalışmalarda da sayısal ve orantısal anlamda artışlar yaşanmıştır. En fazla yükselme ise tez sayısı 1'den 18'e çıan ulusal ve yabancı basının bir arada ele alındığı araştırmalarda gerçekleşmiştir. 


\begin{tabular}{|c|c|c|c|c|}
\hline \multicolumn{5}{|c|}{$\begin{array}{c}\text { Tablo 14: Tezlerin Yıllara ve İnceleme Ölçeklerine } \\
\text { Göre Dağllımları }\end{array}$} \\
\hline \multirow{2}{*}{ İncelenen Evrenler } & \multicolumn{4}{|c|}{ Tezlerin Yapıldığı Dönemler } \\
\hline & $\begin{array}{c}\text { 1. Dönem } \\
\text { 1985-1997 }\end{array}$ & $\begin{array}{c}\text { 2. Dönem } \\
\text { 1998-2005 }\end{array}$ & $\begin{array}{c}\text { 3. Dönem } \\
\text { 2006-2016 }\end{array}$ & Toplam \\
\hline \multirow{2}{*}{ Yerel Basin } & 2 & 3 & 14 & 19 \\
\hline & $11 \%$ & $4 \%$ & $5 \%$ & $5 \%$ \\
\hline \multirow{2}{*}{ Ulusal Basın } & 16 & 71 & 253 & 340 \\
\hline & $84 \%$ & $84 \%$ & $83 \%$ & $83 \%$ \\
\hline \multirow{2}{*}{ Yabancı Bas ın } & & 3 & 16 & 19 \\
\hline & & $4 \%$ & $5 \%$ & $5 \%$ \\
\hline \multirow{2}{*}{$\begin{array}{l}\text { Ulus al ve Yabancı } \\
\text { Basin }\end{array}$} & & 1 & 18 & 19 \\
\hline & & $1 \%$ & $6 \%$ & $5 \%$ \\
\hline \multirow{2}{*}{ Değerlendirilemeyen } & 1 & 7 & 4 & 12 \\
\hline & $5 \%$ & $8 \%$ & $1 \%$ & $3 \%$ \\
\hline Toplam & 19 & 85 & 305 & 409 \\
\hline
\end{tabular}

\section{Sonuç}

Bibliyometrik yöntemi kullanarak gazete haberlerini konu alan ve ideoloji tartışması yürüten yüksek lisans tezlerini değerlendirdiğimiz bu çalışmada 409 tezin üniversitelere ve yıllara göre nasıl bir dağılım gösterdiği ortaya konulmuştur. Yapılan incelemenin sonuçlarına göre Türkiye'de iletişim anabilim dalları altında gazete haberlerini konulaştıran ilk yüksek lisans tezi, 1985 yılında Anadolu Üniversitesi'nde kabul edilmiştir. Bu tarihten 2017 yılına kadar yapılan tez sayısı yıl bazında genellikle yükselerek devam etmiş ${ }^{30}$ özellikle 2006 sonrası önemli miktarda artış yaşamıştır. 1985 - 2006 arası 104 tez tamamlanırken 2006 sonrası 305 çalışma teslim edilmiştir.

Orantısal olarak incelediğimizde evrendeki tezlerin yüzde 75’ü Anadolu, Ankara, Ege, Gazi, İstanbul, Marmara ve Selçuk Üniversitelerinde yapılmıştır. Bunun nedeni ise Türkiye'de iletişim eğitiminin önce bu üniversitelerde başlamasıdır. Eğitimin erken başlamasına rağmen sadece Marmara Üniversitesi'nde gazete haberlerini konu alan tezler 1990'ların ikinci yarısından itibaren yapılmaya başlanmıştır. Bu verilerden hareketle gazete haberlerinin içeriği üzerinden ideoloji tartışmasının iletişim alanında lisansüstü eğitimin başladığından itibaren yapıldığını söylemek mümkündür.

Anabilim dalı özelinde evrendeki çalışmaların yüzde 50'si gazetecilikte yapılmıştır. Bu noktada Ankara ve Gazi Üniversitelerinin Gazetecilik Anabilim Dalları sayıca fazla çalışma tamamlanması nedeniyle ön plana çıkmaktadır. Gazetecilik anabilim dalında yapılan çalışmalar evrenin önemli bir çoğunluğunu oluştururken özellikle 2006 sonrası halkla ilişkiler ve radyo televizyon ve sinema anabilim dalları altında da gazete haberi üzerinden ideoloji tartışması yapıldığı görülmüştür. Bu da iletişim alanının alt dalları arasında sınırların net olmadığını ve geçişkenliliğin 2006 sonrası arttığını bize göstermiştir. Bu geçişkenlik özellikle halkla ilişkiler anabilim dalında gazete haberlerini konu alan en çok tezin yapıldığı Ankara Üniversitesi'nde daha belirgindir.

\footnotetext{
${ }^{30} \mathrm{Bu}$ artış sadece gazete haberlerini konu alan yüksek lisans tezleri bağlamında yaşanmamıştır. Türkiye'de 1985 sonra lisansüstü eğitim için birçok iletişim anabilim dalı açılmıştır. Bu duruma bağlı olarak da öğrenci ve yapılan tez sayısı yıllar içerisinde artış göstermiştir.
} 
Konu bağlamında ele aldığımızda, evrendeki tezlerde güncel siyaset diğerlerine oranla daha fazla tartışılmıştır. Ancak 2006 sonrası kimlik konusu üzerinden yapılan ideoloji tartışmalarında önemli miktarda orantısal artış (yüzde 9'dan 15'e) vardır. Bu bize kültür odaklı tartışmaların yükselme içerisinde olduğunu göstermektedir. Kimlik konusunun en çok tartışıldığı okul Ankara Üniversitesi'dir. Güncel siyaset ise en fazla Ankara ve Gazi Üniversitelerinde yapılan tezlerde ele alınmıştır. Bunlara ek olarak siyaseti merkezine alan çalışmalar yüksek lisans tezlerinde hâkimiyetini kurmuşken spor gibi toplumsal yaşamda yer edinmiş konular üzerinden ideoloji tartışması daha geri planda kalmıştır.

Evrendeki çalışmaların kuramsal yaklaşımlarında eleştirel bakış açıları daha ağır basmaktadır. Üniversiteler bağlamında kuramsal yaklaşımlar net bir biçimde iki okulda ön plana çıkmıştır. Ankara Üniversitesi'nde eleştirel, Anadolu Üniversitesi’nde de anaakım gelenek sayısal olarak ağırlığını koymuştur. Eleştirel çalışmaların alt başlıklarında gerçekliğin ideolojik biçimde çarpıtıldığını ve bunda da basının etkin bir araç olarak kullanıldığını savunan araştırmalar ise çoğunluktadır. Ancak sayısal ağırlık bu şekilde olmakla birlikte inşacı tezlerin dönemlere göre orantısal artışı (sırasıyla yüzde $5,14,23$ ) daha yüksektir. Bu da konu başlığında olduğu gibi kültür temelli bakış açısının yüksek lisans seviyesinde hızla arttı̆̆ının göstergesidir. Son olarak tez sayısındaki orantısal değişime değinirsek eleştirel yaklaşımlar ağırlı̆̆ını arttırarak (sırasıyla yüzde 16, 50, 59) devam ettirmiş, anaakım yaklaşımların benimsenmesi ise orantısal olarak düşüş (sırasıyla yüzde 58, 42,34) yaşamıştır.

Yöntem başlı̆̆ını sayısal veriler üzerinden ele aldığımızda, evrendeki çalışmalarda içerik analizi ağırlığını korumakta, arkasından ise (eleştirel) söylem çözümlemesi gelmektedir. Özellikle 2006 yllından sonra (eleştirel) söylem çözümlemesinin tek başına ve içerik analiziyle birlikte kullanımında önemli bir orantısal artış yaşanmıştır. Sayıca fazla tezin tamamlandığı üniversiteler arasında orantısal ağırlıklara baktığımızda (eleştirel) söylem çözümlemesi Selçuk Üniversitesi’nde, içerik analizi Anadolu Üniversitesi'nde ön plandadır. Kuram ve yöntem verilerini birbiriyle ilişkilendirerek incelediğimizde ise tartışmalı bir durum ortaya çıkmaktadır. İncelediğimiz tezlerde ağırlıkla eleştirel yaklaşımların benimsenmesi ve içerik analizinin oldukça fazla çalışmada kullanılması, eleştirel çalışmalarda anaakım yöntemin tercih edildiğini bize göstermektedir. Bu da kuramsal ve yöntemsel olarak bir çelişkiye işaret etmektedir.

Evrendeki çalışmaların hipotez durumuna bakarsak gazete haberlerini konu alan yüksek lisans tezlerinde hipotez kurmamak daha fazla tercih edilmiştir. Dönemsel olarak 2006 yılına kadar tamamlanmış tezlerin çoğunun içeriğine erişilemediği için bu döneme kadar yapılan çalışmalardan hipotez konusunda sağlıklı veriler elde edilememiştir. ${ }^{31}$ Sadece son dönemdeki tezlere bakılmış ve değerlendirme yapılabilmiştir. Yüksek miktarda tezin teslim edildiği okullar arasında ağırlıkla olmasa da Ankara ve Gazi Üniversitelerinde hipotez diğer üniversitelere göre daha fazla kurulmuş, İstanbul Üniversitesi'nde ise sayıca daha az çalışmada hipotez sınanmıştır.

Son olarak nicel veriler bağlamında evrendeki yüksek lisans tezlerini inceledikleri gazetelerin kapsamlarına göre ele aldığımızda, yerel basının oldukça düşük seviyede konu edildiğini görülmüştür. Özellikle yüksek sayıda tezin teslim edildiği üniversiteler arasında Ankara ve Kocaeli'de yerel basının hiç tartışılmaması dikkat çekicidir. Yerel basının bu derece görmezden gelinmesi 1980

\footnotetext{
${ }^{31} 2006$ öncesi yapılan tezlere bu şekilde erişimin mümkün olmaması araştırmacıların literatür hakkında bilgi edinmesinin önünde engel teşkil etmektedir. Erişilemeyen tezler ise yazar tarafından kısıtlanmış olanlar değil, dijital haliyle YÖK'e teslim edilmemiş araştırmalardır. YÖK Ulusal Tez Merkezi'nin bu konuda bir çalışma yapması ihtiyacı ortadadır.
} 
sonrasında uygulanan neo-liberal politikaların sonucunda piyasanın ulusal basına odaklanmasının akademiye yansıması biçiminde okunabilir. Bunlara ek olarak ulusal ve yabancı basının birlikte ele alındığı çalışmaların sayısında 2006 sonrası önemli bir artış (1'den 18'e) yaşanmıştır.

\section{Kaynakça}

Aktaş, M. \& Özdemir, P. (2006). Disiplinlerarası Bir Alan Olarak Halkla İlişkiler: Türkiye'deki Akademik Çalışmalar Üzerine Niteliksel Bir İnceleme. Sunulan Bildiri, 2. Halkla İlişkiler Sempozyumu: 21. Yüzyılda Halkla İlşkilerde Yeni Yönelimler, Sorunlar ve Çözümler, Kocaeli.

Akyürek, R. (1985). Günlük Gazetelerin Magazin Eklerinin Biçim ve İçerik İncelemesi. (Yayımlanmamış Yüksek Lisans Tezi). Anadolu Üniversitesi Sosyal Bilimler Enstitüsü, Eskişehir.

Ateş, E. K. (2016). Bir Bilim Dalı Olarak İletişim Bilimleri Alanının Türkiye'deki Konusal Kapsam Analizi The Journal of Academic Social Science Studies, 51(3), 217-228. doi:http://dx.doi.org/10.9761/JASSS3692.

Atılgan, G. (2015). İdeoloji. G. Atılgan ve E. A. Aytekin (Eds.), Siyaset Bilimi içinde (s. 285-298). İstanbul: Yordam.

Aydın, A. Ş. (2016). Sağlık Haberlerinde Kadın Bedeninin Sunumu. (Yayımlanmamış Yüksek Lisans Tezi). Marmara Üniversitesi Sosyal Bilimler Enstitüsü, İstanbul.

Aydoğan, A. (2006). Yeni İletişim Teknolojileri Tezlerinde Neo-Klasik İktisat Paradigmasının Hegemonyası. Kültür ve İletişim Dergisi, 9(1), 89-112. url'si. http://ki.imge.com.tr/

Broadus, R. N. (1987). Toward a Definition of Bibliometrics. Scientometrics, 12(5-6), 373-379. url'si. https://link.springer.com/journal/11192/12/5

Çam, Ş. (2008). Medya Çalışmalarında İdeoloji Yaklaşımlarına İlişsin Epistemolojik ve Yöntemsel Sorunlar. Ankara: De Ki.

Çetin, M., Yaşin, C. \& Sönmez, B. (2016). Türkiye'de Halkla İlişkiler Alanındaki Doktora Tezleri Üzerinden Alanda Yapılan Çalışmaların Değerlendirilmesi. İletişim Kuram ve Araştırma Dergisi, Gazi Üniversitesi İletişim Fakültesi Dergisi, 43, 242-264. url'si. http://www.idealonline.com.tr/IdealOnline/lookAtPublications/paperDetail.xhtml?uId=5121 6

Çilingir, A. (2017). İletişim Alanında İçerik Analizi Yöntemï Kullanılarak Yapılan Yüksek Lisans ve Doktora Tezleri Üzerine Bir İnceleme. Akademia, 5(1), 148-160. url'si. http://dergipark.gov.tr/erciyesiletisim/issue/27688/291891

Demirkürek, İ. (2003). Türkiye Basınında Azınlıklar ve Marjinal Gruplar. (Yayımlanmamış Yüksek Lisans Tezi). Kocaeli Üniversitesi/Sosyal Bilimler Enstitüsü, Kocaeli,

Diodato, V. P. (2012). Dictionary of Bibliometrics: Routledge.

Donohue, J. C. (1972). A Bibliometric Analysis of Certain Information Science Literature. Journal of the American Society for Information Science, 23(5), 313-317. doi:https://doi.org/10.1002/asi.4630230506

Dursun, Ç. (2004). Türkiye'de Haber ve Habercilik Çalışmalarının Genel Bir Değerlendirmesi: 19802003. Ç. Dursun (Ed.), Haber, Hakikat ve İktidar İlişkisi içinde (s. 89 - 147): Elips.

Eagleton, T. (2015). İdeoloji (M. Özcan, Çev.). İstanbul: Ayrıntı. 
Garfield, E. (2009). From The Science of Science to Scientometrics Visualizing The History of Science with HistCite Software. Journal of Informetrics, 3(3), 173-179. doi:10.1016/j.joi.2009.03.009

Gazete, R. (13 Aralık 1979). Eskişehir İktisadi ve Ticari İlimler Akademisi Televizyon ile öğretim ve Eğitim Fakültesi (TÖEF) Doktora Yönetmeliği Resmi Gazete(16838 sayllı).

Heywood, A. (2014). Siyasi İdeolojiler. Ankara: Adres.

İnceoğlu, Ç. (2014). Türkiye'de Sinemayı Konu Alan Doktora Tezleri Üzerine Bibliyometrik Bir Çözümleme. Galatasaray Üniversitesi İletişim Dergisi, 21, 31-50. doi:https://dx.doi.org/10.16878/gsuilet.96674

Kuhn, T. S. (2017). Bilimsel Devrimlerin Yapısı (N. Kuyaş, Çev.). İstanbul: Kırmızı.

Lancaster, F. W. (1991). Bibliometric Methods in Assessing Productivity and Impact of Research: Sarada Ranganathan Endowment for Library Science.

McLellan, D. (2009). İdeoloji. İstanbul: İstanbul Bilgi Üniversitesi.

Nicholas, D. \& Ritchie, M. (1978). Literature and Bibliometrics. London: Clive Bingley.

Okay, A. \& Okay, A. (2008). Türkiye'de Lisans ve Lisansüstü Halkla İlişkiler Eğitimi: Tezlerin Halkla İlişkiler Alanına Katkısının Kantitatif Bir Çalışması (1984-2007). Selçuk İletişim, Selçuk Üniversitesi İletişim Fakültesi Dergisi, 5(2), 5-14. url'si. http://josc.selcuk.edu.tr/article/view/1075000175

Okubo, Y. (1997). Bibliometric Indicators and Analysis of Research Systems: Methods and Examples. Paris: OECD Science Technology and Industry Working Papers 1997/01, OECD Publishing.

Osareh, F. (1996). Bibliometrics, Citation Analysisc and Co-Citation Analysis: A Review Of Literature I. Libri, 46, 149-158.

Özer, Ö. (2011). Haber Söylem İdeoloji. İstanbul: Literatürk Academia.

Pritchard, A. (1969). Statistical Bibliography or Bibliometrics? Journal of Documentation, 25(4), 348349. url'si. https://www.emeraldinsight.com/toc/jd/25/4

Sarıer, O. (2014). Halkla İlişkiler Alanında Tamamlanmış Lisansüstü Tez Çalışmalarının İncelenmesi (2003-2012). (Yayınlanmamış Yüksek Lisans Tezi). Gazi Üniversitesi Sosyal Bilimler Enstitüsü, Ankara.

Sengupta, I. N. (1992). Bibliometrics, İnformetrics, Scientometrics and Librametrics: An Overview. Libri, 42, 75-98.

Tokgöz, O. (2003). Türkiye'de İletişim Eğitimi: Elli Yıllık Bir Geçmişin Değerlendirilmesi. Kültür ve İletişim Dergisi, 6(1), 9-32. url'si. http://www.ilefarsiv.com/ki/yazi_87.htm

Tokgöz, O. (2006a). Türkiye'de İletişim Fakültelerindeki Eğitim Kadrosunun Konumu Eleştirel Bir Değerlendirme. Kültür ve İletişim Dergisi, 9(1), 33-70. url'si. http://www.ilefarsiv.com/ki/yazi_58.htm

Tokgöz, O. (2006b). Türkiye'de İletişim Araştırmalarında İletişim Eğitiminin Rolü ve Önemi. Küresel İletişim Dergisi, Bahar(1), 1-12. url'si. http://globalmedia-tr.emu.edu.tr/

Tokgöz, O. (2015a). Başlangıçtan Günümüze Türkiye'de İletişim Araştırmaları: Eleştirel Bir Değerlendirme. B. Yıldırım (Ed.), İletişim Araştırmalarında Yöntemler içinde (s. 15-46). Konya: Literatürk Academia.

Türktarhan, G. (2013). Türkiye'de Turizm Pazarlaması Alanyazınının Gelişim Süreci (1990-2012). (Yayımlanmamış Yüksek Lisans Tezi). Anadolu Üniversitesi Sosyal Bilimler Enstitüsü, Eskişehir. 
Uşkul, E. (2016). Türkiye'de Eğitimde Ölçme ve Değerlendirme Alanında Yapılmış Bilimsel Yayınların Sosyal Ă̆ Analizi ile Değerlendirilmesi: Bir Bibliyometrik Çalışma. (Yayımlanmamış Yüksek Lisans Tezi). Akdeniz Üniversitesi Eğitim Bilimleri Enstitüsü, Antalya.

Ünvanlı, R. (2015). Hekime Yönelik Şiddetin Türk Basınına Yansıması (Yayımlanmamış Yüksek Lisans Tezi). Gazi Üniversitesi Sosyal Bilimler Enstitüsü, Ankara.

Yüksel, E. (1996). Türk Basınının Gelişiminde Basında Ekonomi ve Ekonomi Basını: Kavram ve Kapsam Açısından Uygulamalı Bir Çalışma. (Yayımlanmamış Yüksek Lisans Tezi). Anadolu Üniversitesi/Sosyal Bilimler Enstitüsü, Eskişehir,

Yüksel, H. (2016). Türkiye'deki Hakim İletişim Kavramsallaştırmasının Gelişimi ve Sınırlılıkları. Kültür ve İletişim Dergisi, 38, 10-41. url'si. http://ki.imge.com.tr/ 